Discussion Paper No. 10-082

\title{
Predation Enforcement Options: An Evaluation Using a Cournot Framework
}

Kai Hüschelrath and Jürgen Weigand

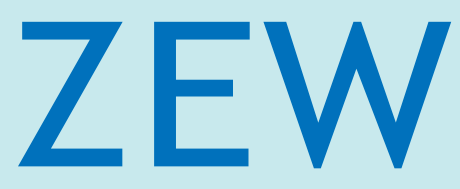

Zentrum für Europäische Wirtschaftsforschung $\mathrm{GmbH}$

Centre for European

Economic Research 
Discussion Paper No. 10-082

\section{Predation Enforcement Options: An Evaluation Using a Cournot Framework}

Kai Hüschelrath and Jürgen Weigand

Download this ZEW Discussion Paper from our ftp server:

ftp://ftp.zew.de/pub/zew-docs/dp/dp10082.pdf

Die Discussion Papers dienen einer möglichst schnellen Verbreitung von neueren Forschungsarbeiten des ZEW. Die Beiträge liegen in alleiniger Verantwortung der Autoren und stellen nicht notwendigerweise die Meinung des ZEW dar.

Discussion Papers are intended to make results of ZEW research promptly available to other economists in order to encourage discussion and suggestions for revisions. The authors are solely responsible for the contents which do not necessarily represent the opinion of the ZEW. 


\section{Non-technical summary}

From a competition policy perspective, predatory behaviour ('predation') has always been a rather controversial issue. For example, while some commentators doubt that such forms of behaviour play a significant role in real markets, others argue that predation can very well be a rational strategy for incumbents facing an entry threat. In addition to the discussions on the rationality of predation, researchers and practitioners were involved in controversial exchanges on the question how predation should be detected in actual competition cases. This strand of research concentrated on the derivation of suitable cost concepts on the one hand, and the design of entire investigation frameworks on the other hand.

Given the detailed discussions on the rationality and detection of predation, it comes as a surprise that the existing literature largely ignores the complementary final step in an antitrust investigation, namely the question how to intervene against detected predators. This lack of research is unfortunate for especially two reasons. First, from a theoretical perspective, the key aim of an efficient implementation of a deterrence-based antitrust policy can only be reached by sending out clear signals to possible predators about the legal consequences of such misconduct. Second, from a practical perspective, the witnessed significant increase in successful predation cases in the European Union immediately raise the question how competition authorities and courts should intervene against (detected) predators.

Against this background, the paper commences with a brief characterisation of the building blocks of a framework to enforce anti-predation rules and subsequently evaluates selected enforcement options in a Cournot-type duopoly predation model. Differentiating between a no rule approach, an ex ante approach and two ex post approaches, it is shown that an ex post approach typically maximises overall welfare. However, an ex ante approach can be the preferred option in cases where the entrant has a large cost advantage over the incumbent. 


\section{Das Wichtigste in Kürze}

Aus wettbewerbspolitischer Sicht sind die Meinungen $\mathrm{zu}$ den verschiedenen Formen marktverdrängender wettbewerbsaverser Verhaltensweisen (sog. ,Predation') schon immer kontrovers gewesen. So zweifeln manche Kommentatoren an, dass solche Verhaltensweisen in realen Märkten überhaupt eine signifikante Bedeutung zukommt, während andere argumentieren, dass Predation sehr wohl eine rationale Strategie für alteingesessene Unternehmen sein kann, die sich Markteintritten konfrontiert sehen. Zusätzlich zu diesen Diskussionen über die Rationalität von Predation waren sowohl Wissenschaftler als auch Praktiker in kontroverse Diskussionen im Bezug auf die Frage involviert, wie Predation in realen Wettbewerbsfällen aufgedeckt werden soll. Dieser Forschungsschwerpunkt konzentrierte sich einerseits auf die Ableitung geeigneter Kostenkonzepte sowie andererseits die Ausgestaltung ganzheitlicher Untersuchungsschemata.

Angesichts dieser detaillierten Diskussionen zur Rationalität und Aufdeckung von Predation-Strategien ist es überraschend festzustellen, dass die bestehende Literatur den komplementären letzten Schritt in der wettbewerbspolitischen Untersuchungsabfolge weitgehend ignoriert, nämlich die Frage, wie man gegen Unternehmen vorgehen soll, die der Anwendung einer Predation-Strategie überführt wurden. Diese Forschungslücke muss aus zwei Gründen heraus als unglücklich angesehen werden. Einerseits kann aus theoretischer Sicht nur dann eine effiziente Implementierung einer abschreckungsbasierten Wettbewerbspolitik erreicht werden, wenn klare Signale an die Unternehmen ausgesendet werden, welche rechtlichen Folgen ein entsprechendes Fehlverhalten hat. Anderseits kann aus praktischer Sicht festgestellt werden, dass in der jüngeren Vergangenheit ein signifikanter Anstieg in der Zahl erfolgreicher Predation-Fälle in der Europäischen Union zu verzeichnen war und somit die Frage aufgeworfen wird, wie Wettbewerbsbehörden und Gerichte mit überführten Unternehmen umgehen sollen.

Vor diesem Hintergrund beginnt der Beitrag mit einer kurzen Charakterisierung der wesentlichen Bestandteile eines wettbewerbspolitischen Untersuchungsschemas für Predation um in der Folge dann ausgewählte Möglichkeiten der Verfolgung solcher untersagten Verhaltensweisen wohlfahrtsökonomisch zu evaluieren und zwar mit Hilfe eines DuopolPredation Modells à la Cournot. Basierend auf einer Unterscheidung in einen ,no rule“ Ansatz, einen ,ex ante' Ansatz sowie zwei ,ex post' Ansätze wird gezeigt, dass ein ex post Ansatz typischerweise die Gesamtwohlfahrt maximiert. Ein ,ex ante` Ansatz kann aber dann die beste Wahl sein, wenn das eintretende Unternehmen einen großen Kostenvorteil im Vergleich zum alteingesessenen Unternehmen aufweist. 


\title{
PREDATION ENFORCEMENT OPTIONS: AN EVALUATION USING A COURNOT FRAMEWORK
}

\author{
Kai Hüschelrath * \\ ZEW Centre for European Economic Research \\ WHU Otto Beisheim School of Management \\ Jürgen Weigand $\#$ \\ WHU Otto Beisheim School of Management
}

\begin{abstract}
The paper characterises the building blocks of a framework to enforce antipredation rules and subsequently evaluates selected enforcement options in a Cournot-type duopoly predation model. Differentiating between a no rule approach, an ex ante approach and two ex post approaches, it is shown that an ex post approach typically maximises overall welfare. However, an ex ante approach can be the preferred option in cases where the entrant has a large cost advantage over the incumbent.
\end{abstract}

Keywords Competition policy, monopolisation, predation, enforcement

JEL Class K21, L41

* Senior Researcher, ZEW Centre for European Economic Research, Department for Industrial Economics and International Management, L7,1, 68161 Mannheim, Germany and Assistant Professor of Industrial Organization and Competitive Strategy, WHU Otto Beisheim School of Management, Burgplatz 2, 56179 Vallendar, Germany, E-Mail: hueschelrath@zew.de. We would like to thank Peter Møllgaard for valuable comments. The usual disclaimer applies.

* Professor of Economics, WHU Otto Beisheim School of Management, Burgplatz 2, 56179 Vallendar, Germany, E-Mail: jweigand@whu.edu. 


\section{Introduction}

Predatory behaviour typically occurs in two phases: a predation phase and a recoupment phase. In the predation phase, the predator tenders a product that offers 'too much value' to consumers (e.g., the price is too low, the quality is too high, or the product is too innovative) and thus weakens rivals. In the recoupment phase, the predator takes advantage of the weakened rival and reduces the consumer value of its products to a level below the competitive one.

From a competition policy perspective, predatory behaviour ('predation') has always been a rather controversial issue. For example, while some commentators doubt that such forms of behaviour play a significant role in real markets, others argue that predation can very well be a rational strategy for incumbents facing an entry threat. In addition to the discussions on the rationality of predation, researchers and practitioners were involved in controversial exchanges on the question how predation should be detected in actual competition cases. This strand of research concentrated on the derivation of suitable cost concepts on the one hand, and the design of entire investigation frameworks on the other hand.

Given the detailed discussions on the rationality and detection of predation, it comes as a surprise that the existing literature largely ignores the complementary final step in an antitrust investigation, namely the question how to intervene against detected predators. This lack of research is unfortunate for especially two reasons. First, from a theoretical perspective, the key aim of an efficient implementation of a deterrence-based antitrust policy can only be reached by sending out clear signals to possible predators about the legal consequences of such misconduct. Second, from a practical perspective, the witnessed significant increase in successful predation cases in the European Union such as $\operatorname{Napp}^{1}$ (UK, 2001), Lufthansa ${ }^{2}$ (GER, 2002), Wanadoo ${ }^{3}$ (EU, 2003) and Aberdeen Journal ${ }^{4}$ (UK, 2004) immediately raise the question how competition authorities and courts should intervene against (detected) predators.

Against this background, the paper commences with a brief characterisation of the building blocks of a framework to enforce anti-predation rules and subsequently evaluates selected enforcement options in a Cournot-type duopoly predation model. Differentiating between a no rule approach, an ex ante approach and two ex post approaches, it is shown that an ex post approach typically maximises overall welfare. However, an ex ante approach can be the preferred option in cases where the entrant has a large cost advantage over the incumbent.

\section{Building blocks of a framework to enforce anti-predation rules}

In this section, the building blocks of a framework to enforce anti-predation rules are briefly characterized in order to allow an economic evaluation of selected enforcement options in the preceding section. The construction of the framework largely follows Hüschelrath and Weigand (2010).

\subsection{Characterising predation}

A fairly large number of definitions of predation exist. Cabral and Riordan (1997: 160), for example, define an action as 'predatory' if "a different action would increase the likelihood that rivals remain viable and ... the different action would be more profitable under the counterfactual hypothesis that the rival's viability were unaffected." According to Farrell and Katz (2001: 2), predatory behaviour can be schematically thought of as occurring in two

\footnotetext{
Napp Pharmaceutical Holdings Ltd. and Subsidiaries v. Director General of Fair Trading, CA98/2/2001 (2001).

Beschluss in dem Verwaltungsverfahren gegen Deutsche Lufthansa AG, Köln, B 9-144/01 (2002).

COMP/38.233 - Wanadoo Interactive (2003).

Predation by Aberdeen Journal Ltd., CA98/5/2001 (2002).
} 
phases: a predation phase and a recoupment phase. In the first phase, the predator tenders a product that offers 'too much value' to consumers (e.g., the price is too low, the quality is too high, or the product is too innovative) and thus weakens rivals. In the second phase, the recoupment phase, the predator takes advantage of the weakened rival and reduces the consumer value of its products to a level below the competitive one.

Based on this initial characterisation, the general business concept of a predation strategy can be clarified by analysing the profits of the incumbent over time. Initially, a market in which a single incumbent sets the profit-maximising (monopoly) price is assumed. The incumbent gains a so-called excess profit, which is defined as the difference between the monopoly profit $\pi^{\text {Mono }}$ and the duopoly profit $\pi^{\text {Duo }}$. At point $t^{\text {entry }}$, a rival firm enters the market. If the incumbent accommodates the rival in the market, both firms would realise $\pi$ Duo. In a Cournot equilibrium, the profits of both firms are assumed to be positive but of different size as long as both firms are not symmetrical in terms of their cost structures and production capacities. If the incumbent accommodates the entrant, it would lose its excess profit.

Besides entry accommodation, the incumbent might think about the possibility of lowering the price, raising the quality, etc., by such an amount that the entrant makes losses and is forced to exit the market at point $t^{\text {exit }}$. Although the incumbent has to sacrifice profits during the predation period, he might regain its old monopoly position and the corresponding monopoly profit $\pi^{\text {Mono }}$ until the market ends or another rival firm enters the market. Based on this simple set-up, the profitability of the predation investment depends on especially five factors: (1) the level of losses in the predation period ( $\left.\pi^{\text {Duo }}-\pi^{\text {Pred }}\right)$; (2) the level of excess profits after the exit of the entrant ( $\left.\pi^{\text {Mono }}-\pi^{\text {Duo }}\right)$; (3) the number of predation periods $\alpha$; (4) the number of periods after the exit of the entrant $\beta$ and (5) the discounting factor of future profits $\delta$.

Recent economic research has focused mainly on factors (2) and (4), namely assessing ways by which the predator can recoup its losses sacrificed in the predation period. The most straightforward answer is that it can achieve changes in market structure by forcing exit so that it can regain excess profits and strengthen its dominant market position. Another channel to reach the necessary recoupment are changes in the nature of competition; for example, the predator obtains a tough reputation and can deter future entry in the same or adjacent markets. A third possibility to recoup the losses of the predation period are changes in the nature of demand, for example, by (additional) consumers switching from the market-leaving entrant to the predator (see Frontier Economics, 2002).

\subsection{Rationalising predation}

Based on the characterisation of predation, deriving the two basic conditions for rational predation is straightforward. First, the use of such a strategy must expect a positive net present value of the investment, meaning that the benefits gained in period two must exceed the cost stemming from period one (effectiveness condition). Second, in the decision situation at hand there must be no superior alternative strategy, meaning that no strategy is available which could reach the same profit level with less cost burden or a higher profit level with the same cost burden (efficiency condition). If one of the two conditions is not fulfilled, predation becomes an irrational strategy and the observed price reductions must be explained differently.

Focusing on the efficiency question first, one frequently cited argument for the irrationality of predation strategies is that in any situation in which predation would be profitable, it is not profit-maximising for a long-run profit-maximising firm. Without trying to prove the theoretical correctness of this proposition (which appears to be challenging at least in a multi- 
market context), it is obviously based on the presumption that acquisition, collusion or accommodation are suitable and reachable strategic answers to market entry for an incumbent. With respect to mergers and acquisitions it is obvious that such a presumption is critical as soon as some kind of merger control procedure is implemented. Such investigations would foreclose (or at least endanger) the success of strategic mergers, especially in cases where aggressive maverick firms are the target. Collusion as an alternative strategy is often confronted with severe agreement and stability problems; and accommodating might generally be a dangerous strategy in the long run, especially if the entrant is more efficient than the incumbent. Moreover, colluding and accommodating can hardly be suitable general strategies for an incumbent in response to entry, as such conduct would reduce the entry risk of potential entrants and therefore would create some kind of 'reputation for faintness'. Consequently, even in the case that other strategies are more efficient in a certain situation, predation can be some kind of second-best way of maintaining a monopoly position.

The effectiveness question is the general focus of most research on predation and produced a multitude of arguments in favour of or against its rationality. Starting with the simple delineation of predation in two periods, the arguments of the opponents are based on two simple, interrelated aspects. First, the incumbent's losses in the first period are severe because of its high market share. Second, the expected gains in the second period are low, in fact, too low to outweigh the severe losses realised in the first period. Some scholars find it implausible, for instance, that the predator can foreclose the market effectively for new entrants in the post-predation period, especially if new entrants can buy the equipment of the market-leaving prey. A further argument states that investors have a profit-driven incentive to help efficient victims with credits to survive the predation period. As a rational predator can foresee this, the predation strategy becomes unprofitable and therefore irrational.

It is the merit of game-theoretic research to have investigated the correctness of such arguments in a rigid analytical framework. The fundamental results show that predatory actions could indeed be optimal strategies in a world of incomplete or asymmetric information. The so-called models of financial market predation address the question of why investors should not have an incentive to help efficient victims to survive the predation period. One answer is that, due to information asymmetries in efficient capital markets, investors do not know exactly the efficiency of the entrant and the entrant has incentives to covey a "misleading optimistic impression of its ability to survive" (Martin, 1994: 461). Given this incomplete information combined with opportunism, investors will not provide capital or at best a risk premium which increases the costs of the entrant.

The signalling and reputation models both consider low prices as instruments of the incumbent to mislead the (less informed) entrant into believing that market conditions are unfavourable for entry. One type of signalling models argues that a low price could (under certain conditions) be interpreted as a signal for the efficiency of the incumbent (e.g., if the entrant believes that the incumbent's low prices reflect low costs). The reputation models focus on the rationality of a price reduction in one market by means of establishing a reputation as a tough price cutter in other markets (see Bolton et al., 2000: 2299ff.). This reputation might induce the entrant to retreat from entering the same or an alternative market in which the incumbent is active.

\subsection{Enforcing predation}

In general, the enforcement of anti-predation rules can be divided into two subsequent stages. The detection stage focuses on how predation should be revealed (and especially distinguished from procompetitive price decreases), while the intervention stage addresses the complementary question of what should be done with firms who applied predation strategies. 


\subsubsection{Detecting predation}

The key finding thus far is that predation can be a rational business strategy. Under the assumption that it typically has negative implications on overall welfare and particularly consumer welfare, the question of how to detect predation in real antitrust cases becomes the crucial next step in the antitrust analysis of predation. Technically, detecting predation basically means that the antitrust authority has to investigate whether the prices of an incumbent are unreasonably low, solely aiming at swamping the entrant out of the market.

Given this basic aim, the usage of an (ex post) per se rule (as an objective indicator) seems to be the obvious antitrust reaction. If the price set by the incumbent is below some measure of cost, it is defined as predatory otherwise it is not. Consistently with this basic argumentation, in 1975, Areeda and Turner (1975: 697ff.) proposed a pure cost-based rule to define and detect predatory pricing in antitrust cases. Under this approach, a price at or above the defendant's average variable cost (applied as a surrogate for short-run marginal cost) is conclusively deemed lawful and a price below the defendant's average variable cost is conclusively deemed unlawful, as a profit-maximising firm would never charge such a price.

Following an extensive use of the Areeda-Turner rule in the first years after its invention, the identification of substantial practical drawbacks (such as its static character and its errorproneness) led to the disappearance of the respective application enthusiasm. In the aftermath, research in antitrust law and economics has focused on especially three major areas to improve the detection of predation strategies. First, considerable effort has been undertaken to develop superior rules which try to avoid several problems of the Areeda-Turner rule (see Brodley and Hay, 1981: 738ff.). Williamson (1977: 284ff.), for instance, invented an (ex ante) 'no post-entry output increase' rule in 1977, followed by Baumol's (ex ante) 'no post-exit price increase' rule two years later (see Baumol, 1979).

Second, more appropriate cost concepts for predation cases have been developed. The most influential proposals of this strand of research are the concept of average avoidable cost by Baumol (1996: 58ff.) and the average incremental cost standard defined by Bolton, Brodley and Riordan (2000), which both address the problem in practical predation cases to distinguish between the various cost test in a multi-product firm context.

Third, an (ex post) two-step standard for the detection of predation strategies was developed as an amendment to the compulsory price-cost comparisons. The basic idea of the standard is that before time-consuming cost calculations are undertaken, the general probabilities of future supra-competitive pricing and recovery of losses by the predator should be considered first to get a rough estimate whether predation could generally be a problem in the market at hand. This proposal was basically motivated by a decision-theoretic framework proposed by Joskow and Klevorick (1979: 218), in which the authors favour a policy "that would minimise the sum of the expected costs of error and the costs of implementation". The cost of error can be classified, as in statistical terminology, as type I and type II errors. A type I error would be an erroneous condemnation of procompetitive behaviour, while the failure to condemn an instance of anticompetitive behaviour would be a type II error.

Recent research has focused mainly on the extension of the two-step standard to a complete (ex post) rule of reason approach, which especially tries to integrate the fundamental gametheoretic insights as well as the new cost concepts sketched above. Current research competition between different frameworks is tough (see, e.g., Bolton et al., 2000, and Mastromanolis, 1998) and becomes increasingly differentiated, as special industries and special industry characteristics (such as network effects) become the focal point of interest (see Oster and Strong, 2001, or Kate and Niels, 2004). Probably the most influential general attempt to construct a full rule of reason approach is the four stages framework of Bolton et al. (2000: 2262ff.). The authors recommend starting case work with an examination of the general market conditions in order to sort out unlikely predation cases, such as those in which 
the defendant does not have market power, no significant entry barriers are present or the respective entrant is strong. The second stage looks for a general scheme of predation and supporting empirical evidence, followed by an assessment of the probability of recoupment in stage three. Subsequently, in stage four, prices and costs are examined, taking the 'average incremental cost' standard into account. The framework is amended by a so-called efficiency defense, which aims at "eliminating cases where below-cost pricing by a firm with market power is likely to be welfare-enhancing, rather than predatory. In these cases, the sacrifice of present profits through low pricing is justified for reasons other than exclusion or disciplining of rivals" (Bolton et al., 2000: 2274). Examples of such reasons include product promotions, penetration pricing in network industries, learning by doing, pricing in systems markets, monopoly with complementary products, irreversible exit, industry rationalisation, encouraging additional infra-marginal sales and disposal of excess or obsolete stock (see Edwards, 2002: 183ff., for a detailed description).

\subsubsection{Intervening against predation}

Detecting is a necessary but not sufficient condition for enforcing. Even the cleverest detection rule remains an academic mind game if it is not applied in the sense that possible infringements are not pursued and possibly punished. As seen in the preceding section, the antitrust authority has the choice between two basic control strategies to ensure respect for legal prohibitions: a per se rule or a rule of reason analysis. It can further choose among two alternatives with respect to the timing of control: ex ante and ex post.

When it comes to intervening against detected behaviour the antitrust authority gains a third decision variable, namely the type of intervention. In general, three types of interventions are available: fines, behavioural remedies and structural remedies. A fine is commonly understood as imprisonment or an amount of money which must be paid for a proved misdemeanour or felony; a remedy comprises all other possible non-pecuniary interventions with either a behavioural or a structural focus. Conceptually, fines and remedies differ considerably, as "[r]emedies cure, correct, or prevent unlawful conduct, whereas sanctions penalise or punish it" (OECD, 2007: 7).

Given this broad delineation of general enforcement actions, the remainder of this paper will concentrate on the four options which are most likely to become implemented in actual competition policy: a no rule approach, two ex post rule of reason approaches and an ex ante per se rule approach. Figure 1 exemplarily sketches the consumer surplus effects of the four enforcement options which will be characterised in greater detail in the following sections. 


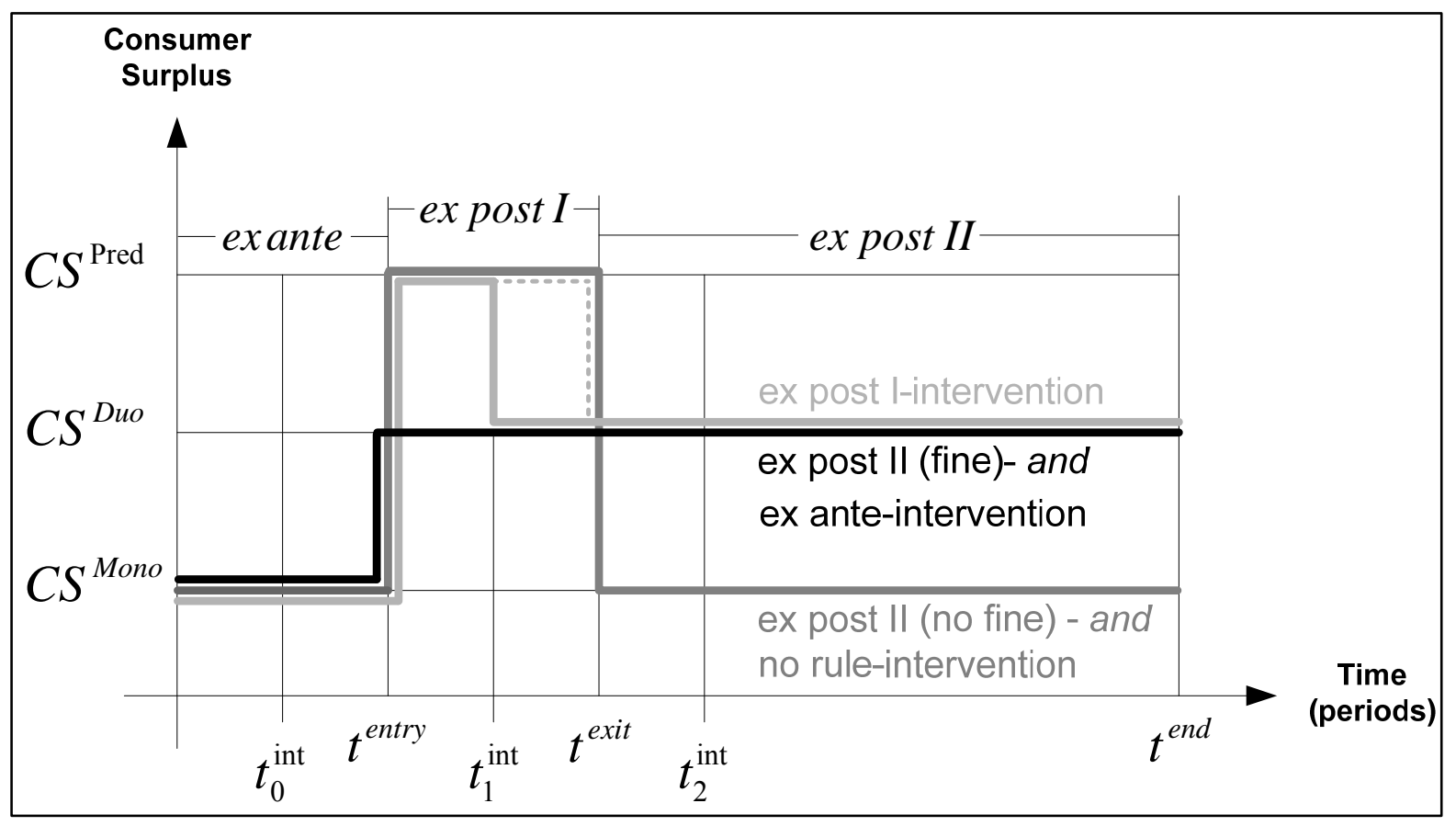

Figure 1: Consumer surplus effects of different enforcement options

\subsubsection{No rule approach}

In a no rule approach, the antitrust authority on principle does not encroach upon any event of unreasonably low prices. Consequently, the incumbent is able to implement its predation strategy and swamps out the rival at point $t^{\text {exit }}$. The consumers can enjoy the additional high consumer surplus during the predation period but are condemned, after the forced exit of the rival, to the high monopoly price and the correspondingly low consumer surplus until the market ends or another firm enters the market at point $t^{\text {end }}$.

The overall welfare effect of a predation strategy under a no rule approach can be derived by adding up the three welfare components: consumer surplus, producer surplus of the incumbent and producer surplus of the entrant. If the predation attempt of the incumbent is successful, it is shown in Annex 5.1 that the net overall welfare would still increase compared to a continuation of the monopoly situation - as long as

$$
\mathrm{CS}^{\text {Pred }}-\mathrm{CS}^{\text {Mono }}>\pi_{\mathrm{I}}^{\text {Mono }}-\left(\pi_{\mathrm{E}}^{\text {Pred }}+\pi_{\mathrm{I}}^{\text {Pred }}\right) .
$$

Inequality (1) basically says that the consumer surplus gain in the predation period has to be larger than the loss in producer surplus in the same period to increase overall welfare. As predation is assumed to be successful, the market performance in the post-predation period is the same as in a 'continuous monopoly' counterfactual scenario and therefore of no relevance for calculating the net welfare effect.

In an alternative scenario, it is assumed that predation is unsuccessful for the incumbent because the entrant somehow survives the predation period. Comparing such a situation with the realised welfare in the scenario of successful predation, it is shown in Annex 5.2 that the net welfare increases as long as

$$
\mathrm{CS}^{\text {Duo }}-\mathrm{CS}^{\text {Mono }}>\pi_{\mathrm{I}}^{\text {Mono }}-\left(\pi_{\mathrm{E}}^{\text {Duo }}+\pi_{\mathrm{I}}^{\text {Duo }}\right) \text {. }
$$

Inequality (2) says that the consumer surplus gain due to increased competition (in the postpredation period) must be larger than the loss in producer surplus due to competition (in the post-predation period) in order to realise a net increase in overall welfare. Due to the deadweight loss caused by monopoly prices, this condition typically holds, and the welfare 
gain increases with the spread between the pre-predation price level and the price level which would exist under perfect competition. However, there are situations - such as the so-called natural monopoly - in which the derived inequality would not hold.

\subsubsection{Ex post rule of reason}

Under an ex post approach, the antitrust authority's aim is to take appropriate action against predation strategies during or after the infringement occurred. Depending on intervention timing, an ex post I approach and an ex post II approach can be distinguished. Under the former, the antitrust authority ends the infringement before the entrant is forced to leave the market (at point $\mathrm{t}_{1}^{\mathrm{int}}$ ). ${ }^{5}$ In such a case, the consumers are able to enjoy a period of low prices before the intervention and still get the duopoly price and the corresponding duopoly consumer surplus after the intervention of the antitrust authority until the market ends. In terms of overall welfare, inequality (2) above has already defined the condition under which an ex post I approach is superior to a no rule approach. Under the ex post II approach, the antitrust authority intervenes after the prey already left the market (at point $\mathrm{t}_{2}^{\mathrm{int}}$ ). In such a situation, the antitrust authority cannot force the incumbent to set the duopoly price and the consumers would only realise the small monopoly consumer surplus in the post-predation period. However - as part of an ex post II approach - the antitrust authority normally imposes a fine for the proved misdemeanour or felony.

The economically appropriate way to fix the level of such a fine is the subject of ongoing discussions among antitrust scholars. Simply the aim of setting antitrust fines is one hotbed of dispute. While some scholars see fines as an important instrument in the prevention of violations (i.e., the creation of a deterrence effect), others understand fines more as reparation of the harm caused by the misdemeanour or felony (see Wils, 2002: 10ff., for a detailed discussion). Although both concepts do not necessarily fall foul with each other, it is shown below that both concepts can lead to quite different fine levels.

With respect to the ex post II approach in predation enforcement, a deterrence effect would not be reached as long as the fine simply reduces but not matches the expected (net) excess profits of the incumbent (ex post II (no fine) approach). However, if the antitrust authority can credibly commit ex ante to imposing a fine which takes away that (net) excess profit of

$$
\mathrm{F}_{\text {Gain based }}=\beta\left(\pi_{\mathrm{I}}^{\text {Mono }}-\pi_{\mathrm{I}}^{\text {Duo }}\right)+\alpha\left(\pi_{\mathrm{I}}^{\text {Pred }}-\pi_{\mathrm{I}}^{\text {Duo }}\right)
$$

such an approach would realise the same overall consumer surplus as the ex ante approach sketched below (see Annexes 5.3 and 5.5 for the proofs). This is simply because the incumbent would anticipate before applying the predation strategy that it will get caught and that the fine would take away the excess profit.

Although such a gain-based fine looks justified and attractive in the first place, theoretical research in law and economics has shown that so-called harm-based 'optimal' fines have under fairly general assumptions certain advantages over gain-based fines (see Wils, 2002: 22ff.). In situations, for instance, in which certain forms of behaviour harm the society less than it brings the offender, the offender would still commit the offence (and pay the fine). In such an environment, gain-based fines would lead to over-deterrence, as they would prevent such 'efficient' offences. ${ }^{6}$ Additionally, gain-based fines might also lead to a problem of under-deterrence, which is caused when errors in the estimation of harm/gain occur.

The graph in Figure 1 shows that the realised consumer surplus depends on the exact enforcement timing of the antitrust authority. In order to maximise consumer surplus, it would be optimal to hold back the intervention to the point at which the entrant has to leave the market.

6 This argument is based on the general work of Becker (1968: 169ff.), who shows that even if the enforcement costs are zero, it is not economically justified to deter all violations, as some offences are efficient in the sense that the gain to the offender exceeds the harm to the victim. 
Underestimating the gain would lead to a complete loss of the deterrence effect as the offender would still make a profit while underestimating the harm could still hold up the deterrence effect (as the fine might still be higher than the gain).

Although harm-based fines might indeed have certain advantages over gain-based fines, it is not straightforward how harm should be defined. A frequently used definition for deterring antitrust violations was derived by William Landes (1983: 652ff.) based on the general work of Gary S. Becker (1968). Landes shows that the "optimal penalty should equal the net harm to persons other than the offender" (Landes, 1983: 678). ${ }^{7}$ In the context of predation, the optimal harm-based fine is given by the following expression (see Annex 5.3 for the proof) ${ }^{8}$ :

$$
\mathrm{F}_{\text {Harm based }}=\alpha\left[\left(\mathrm{CS}^{\text {Duo }}-\mathrm{CS}^{\text {Pred }}\right)+\left(\pi_{\mathrm{E}}^{\text {Duo }}-\pi_{\mathrm{E}}^{\text {Pred }}\right)\right]+\beta\left[\left(\mathrm{CS}^{\text {Duo }}-\mathrm{CS}^{\text {Mono }}\right)+\pi_{\mathrm{E}}^{\text {Duo }}\right] .
$$

In the predation period $\alpha$, net harm to others is given by the sum of the difference between the duopoly and predation consumer surplus (harm to consumers) and the difference between the entrant's duopoly and predation profits (harm to other producers). If predation is successful, the net harm to others in the post-predation period $\beta$ is given by the difference between the duopoly and the monopoly consumer surplus and the entrant's duopoly profits it would have earned without a successful predation strategy. The overall net harm to others shown above is just the sum of the two expressions.

This definition of a harm-based fine allows deriving the welfare differential between an ex post I and an ex post II approach. Both approaches realise the same welfare in the predation period. In the post-predation period, however, the approaches differ. The ex post I approach guarantees the duopoly welfare for the whole post-predation period $\beta$, which is given by the expression $\beta\left(\mathrm{CS}^{\text {Duo }}+\pi_{\mathrm{E}}^{\text {Duo }}+\pi_{\mathrm{I}}^{\text {Duo }}\right)$. The welfare realised with an ex post II approach is the sum of the monopoly welfare realised during the whole post-predation period $\beta\left(\operatorname{Cs}^{\text {Mono }}+\pi_{\mathrm{I}}^{\text {Mono }}\right)$ and the harm-based fine imposed by the antitrust authority, $\varepsilon$ periods after the end of the predation period (with $0 \leq \varepsilon \leq \beta$; see Annex 5.4 for the proof)

$$
\begin{aligned}
\left.\mathrm{W}_{\text {Ex post II }}=\alpha\left[\left(\mathrm{CS}^{\text {Duo }}-\mathrm{CS}^{\text {Pred }}\right)+\left(\pi_{\mathrm{E}}^{\text {Duo }}-\pi_{\mathrm{E}}^{\text {Pred }}\right)\right]\right\}+ \\
\varepsilon\left[\left(\mathrm{CS}^{\text {Duo }}-\mathrm{CS}^{\mathrm{Mono}}\right)+\pi_{\mathrm{E}}^{\text {Duo }}\right]
\end{aligned} .
$$

Overall, an ex post I approach is superior to an ex post II approach as long as the following inequality holds

$$
\begin{gathered}
\beta\left(\mathrm{CS}^{\text {Duo }}+\pi_{E}^{\text {Duo }}+\pi_{I}^{\text {Duo }}\right)>\beta\left(\mathrm{CS}^{\text {Mono }}+\pi_{I}^{\text {Mono }}\right)+ \\
\left\{\alpha\left[\left(\mathrm{CS}^{\text {Duo }}-\mathrm{CS}^{\text {Pred }}\right)+\left(\pi_{\mathrm{E}}^{\text {Duo }}-\pi_{\mathrm{E}}^{\text {Pred }}\right)\right\}+\varepsilon\left[\left(\mathrm{CS}^{\text {Duo }}-\mathrm{CS}^{\text {Mono }}\right)+\pi_{\mathrm{E}}^{\text {Duo }}\right]\right\} .
\end{gathered}
$$

Rearranging both sides leads to the following inequality:

$$
\begin{aligned}
& (\beta-\varepsilon)\left(\mathrm{CS}^{\text {Duo }}-\mathrm{CS}^{\text {Mono }}\right)-\alpha\left(\mathrm{CS}^{\text {Duo }}-\mathrm{CS}^{\text {Pred }}\right)> \\
& \beta\left(\pi_{\mathrm{I}}^{\text {Mono }}-\pi_{\mathrm{E}}^{\text {Duo }}-\pi_{\mathrm{I}}^{\text {Duo }}\right)+\alpha\left(\pi_{\mathrm{E}}^{\text {Duo }}-\pi_{\mathrm{E}}^{\text {Pred }}\right)+\varepsilon \pi_{\mathrm{E}}^{\text {Duo }} .
\end{aligned}
$$

In fact, the complete rule says that the "optimal penalty should equal the net harm to persons other than the offender, adjusted upward if the probability of apprehension and conviction is less than one". This second part of the rule becomes relevant in an assessment of optimal enforcement in an imperfect world; see Connor and Lande (2006) and Lande (2004).

8 An alternative definition of harm could be the cost that the violation has imposed on society. That would ignore the distributive effects of a predation strategy (namely, the lower consumer surplus due to higher monopoly profits) and would only focus on the net welfare losses. It can be shown (e.g., with the model and market specification defined below) that such an alternative definition of harm typically cannot reach a deterrence effect, as the gains of the violation are typically larger than the optimal harm-based fine. Only if the entrant has a large efficiency advantage would such a definition of harm-based fine lead to a deterrence effect. 
The inequality suggests that for small $\beta$ and large, an ex post II approach is superior in terms of overall welfare to an ex post I approach. Generally, the value of the positive differential shows how much the antitrust authority should invest at the maximum in the quicker but more expensive ex post I approach to increase overall welfare compared to an ex post II approach.

\subsubsection{Ex ante, per se rule}

Under an ex ante rule approach, the antitrust authority commits itself to a certain entry reaction before an incumbent actually decides to predate. If the antitrust authority credibly announces ex ante (at point $t_{0}^{\text {int }}$ ) that it would, for instance, force the incumbent to keep its post-entry price for a certain period even after the entrant left the market, the costs of the predation period would rise substantially and recoupment possibilities would decline for the incumbent simultaneously. Hence, assuming that such a rule works frictionless, the incumbent's incentives are altered in a way that makes predation unprofitable and therefore irrational. Consequently, the consumers cannot enjoy the high consumer surplus during the predation phase but instead realise the duopoly consumer surplus from the point of entry to the end of the market. ${ }^{9}$ A comparison of the realised welfare with an ex ante, per se rule and an ex post I rule of reason shows (see Annex 5.5 for the proof) that the former is the superior choice as long as

$$
\mathrm{CS}^{\text {Duo }}-\mathrm{CS}^{\text {Pred }}>\pi_{\mathrm{E}}^{\text {Pred }}+\pi_{\mathrm{I}}^{\text {Pred }}-\pi_{\mathrm{E}}^{\text {Duo }}-\pi_{\mathrm{I}}^{\text {Duo }} .
$$

The inequality basically says that an ex ante per rule is superior to an ex post I rule of reason as long as the difference between the consumer surplus in duopoly and predation (in the predation period) is larger than the overall producer surplus difference between predation and duopoly (in the predation period).

\section{Evaluating enforcement options in a linear duopoly predation model}

The aim of the preceding sections was to derive general inequalities which allow a pair-wise comparison of different enforcement options in terms of their effects on overall welfare. Based on typical effects of increased competition, such as increases in consumer surplus and reductions in producer surplus, especially the general welfare differentials of no rule versus continuation of monopoly, ex post I rule versus no rule, ex ante rule versus ex post rule and ex post I versus ex post II rule were characterised in more detail. Furthermore, general expressions for the optimal gain-based and harm-based fines for predation strategies were derived.

Although it was possible to derive certain general propositions about the typical sign of certain welfare differentials, others had to remain undetermined. To allow a more detailed and sophisticated analysis, the next analytical step must be establishing a link between the derived general propositions and a model of competitive interaction. Therefore, in a first step, a linear Cournot model with cost differences will be developed to derive the exact general welfare differentials in a widely accepted model context (Section 3.1). In a second step, these general results will be applied to a particular market specification (i.e., real demand and cost functions). In particular, three different scenarios will be constructed which differ in the assumptions about the efficiency of the incumbent and the entrant (Section 3.2). A discussion of the results of the simulations for the selected enforcement options is provided in Section 3.3 .

In the simple set-up provided by Figure 1, the consumers are better off with an ex ante approach than with a no rule approach as long as the post-predation period is longer than the predation period. 


\subsection{Model specification and general results}

The basic model setup follows a paper by Normann (1994). ${ }^{10}$ It basically assumes a quantitysetting duopoly consisting of an incumbent (former monopoly) firm I and an entrant $E$. The inverse demand function is assumed to be linear $p=a-b\left(q_{I}+q_{E}\right)$ with $\mathrm{a}, \mathrm{b}>0$. Firms produce at constant marginal costs of $C_{I}, C_{E}$ and fixed costs of $F C_{I}, F C_{E}$. Based on this basic set-up, three different market states have to be characterised in terms of its welfare effects: Monopoly, duopoly and predation.

In the monopoly situation, the profit function of the monopolist is given by

$$
\Pi_{\mathrm{I}}=(\mathrm{a}-\mathrm{bQ}) \mathrm{Q}-\mathrm{c}_{\mathrm{I}} \mathrm{Q}-\mathrm{FC}_{\mathrm{I}} \text {. }
$$

The incumbent's profit is maximised by setting the marginal revenue equal to marginal cost, leading to the following quantity provided by the monopolist

$$
\mathrm{Q}^{\mathrm{m}}=\frac{\mathrm{a}-\mathrm{c}_{\mathrm{I}}}{2 \mathrm{~b}} .
$$

Substituting the quantity expression into the demand curve leads to the monopoly price

$$
\mathrm{p}^{\mathrm{m}}=\frac{\mathrm{a}+\mathrm{c}}{2} .
$$

Substituting the quantity expression and the price expression in the monopolist's profit function leads to the monopoly profit

$$
\Pi^{\mathrm{m}}=\frac{(\mathrm{a}-\mathrm{c})^{2}}{4 \mathrm{~b}} .
$$

Finally, the consumer surplus can be derived as

$$
\mathrm{CS}^{\text {Mono }}=\frac{\left(\mathrm{a}-\mathrm{p}^{\mathrm{m}}\right) \mathrm{Q}^{\mathrm{m}}}{2}=\frac{\left(\mathrm{a}-\mathrm{c}_{\mathrm{i}}\right)^{2}}{8 \mathrm{~b}} .
$$

In the duopoly situation, the profit functions of the incumbent and the entrant are given by

$$
\begin{gathered}
\Pi_{\mathrm{I}}=\left(\mathrm{a}-\mathrm{b}\left(\mathrm{q}_{\mathrm{I}}+\mathrm{q}_{\mathrm{E}}\right)-\mathrm{c}_{\mathrm{I}}\right) \mathrm{q}_{\mathrm{I}}-\mathrm{FC}_{\mathrm{I}}, \\
\Pi_{\mathrm{E}}=\left(\mathrm{a}-\mathrm{b}\left(\mathrm{q}_{\mathrm{I}}+\mathrm{q}_{\mathrm{E}}\right)-\mathrm{c}_{\mathrm{E}}\right) \mathrm{q}_{\mathrm{E}}-\mathrm{FC}_{\mathrm{E}} .
\end{gathered}
$$

Both firms maximise their profit functions by choosing their quantity $q$ under the assumption that the quantity of the rival is fixed. The non-cooperative Cournot equilibrium - which serves as a benchmark for procompetitive, non-predatory behaviour - is determined by the interaction point of the two reaction functions in which the equilibrium quantities for I and $\mathrm{E}$ are given by

$$
\begin{aligned}
& \mathrm{q}_{I}^{\mathrm{C}}=\frac{a-2 c_{I}+c_{E}}{3 b}, \\
& \mathrm{q}_{\mathrm{E}}^{\mathrm{C}}=\frac{a-2 c_{E}+c_{I}}{3 b}
\end{aligned}
$$

leading to an equilibrium price of

$$
\mathrm{p}^{\mathrm{C}}=\frac{\mathrm{a}+\mathrm{c}_{\mathrm{I}}+\mathrm{c}_{\mathrm{E}}}{3}
$$

10 Although the basic model was developed by Normann (in an unpublished paper), the set-up of the basic model largely follows Phlips (1995: 241ff.). Phlips applies Normann's model. 
Firm profits in the equilibrium are

$$
\begin{gathered}
\Pi_{\mathrm{I}}^{\mathrm{C}}=\frac{\left(\mathrm{a}-2 \mathrm{c}_{\mathrm{I}}+\mathrm{c}_{\mathrm{E}}\right)^{2}}{9 \mathrm{~b}}-\mathrm{FC}_{\mathrm{I}} . \\
\Pi_{\mathrm{E}}^{\mathrm{C}}=\frac{\left(\mathrm{a}-2 \mathrm{c}_{\mathrm{E}}+\mathrm{c}_{\mathrm{I}}\right)^{2}}{9 \mathrm{~b}}-\mathrm{FC}_{\mathrm{E}} .
\end{gathered}
$$

Finally, the consumer surplus realised in the duopoly state can be calculated to

$$
\mathrm{CS}^{\text {Duo }}=\left(\mathrm{a}-\left(\frac{\mathrm{a}+\mathrm{c}_{\mathrm{I}}+\mathrm{c}_{\mathrm{E}}}{3}\right)\right)\left[\left(\frac{\mathrm{a}-2 \mathrm{c}_{\mathrm{I}}+\mathrm{c}_{\mathrm{E}}}{3 \mathrm{~b}}\right)+\left(\frac{\mathrm{a}-2 \mathrm{c}_{\mathrm{E}}+\mathrm{c}_{\mathrm{I}}}{3 \mathrm{~b}}\right)\right]\left(\frac{1}{2}\right) .
$$

The predation situation is modelled by assuming that the predator sells a quantity such that the entrant makes zero profits. Given the predators sales $q_{I}^{P}$ the entrant produces

$$
q_{E}^{P}=\frac{\left(a-b q_{I}^{P}-c_{E}\right)}{2 b}
$$

as an optimal response. The entrant's profit function can be rewritten as

$$
\Pi_{\mathrm{E}}^{\mathrm{P}}\left(\mathrm{q}_{\mathrm{I}}^{\mathrm{P}}\right)=\left(\frac{\mathrm{a}-\mathrm{bq}_{\mathrm{I}}^{\mathrm{P}}-\mathrm{c}_{\mathrm{E}}}{2}\right)^{2}\left(\frac{1}{\mathrm{~b}}\right)-\mathrm{FC}_{\mathrm{E}}=0 .
$$

Solving this for $\mathrm{q}_{\mathrm{I}}^{\mathrm{P}}$ leads to the following outcomes

$$
\begin{gathered}
q_{I}^{P}=\frac{a-c_{E}}{b}-2 \sqrt{F C_{E} / b}, \\
q_{E}^{P}=\sqrt{F C_{E} / b}, \\
p^{P}=\sqrt{F C_{E} b}+c_{E} .
\end{gathered}
$$

The incumbent's profit in the predation period is given by

$$
\Pi_{\mathrm{I}}^{\mathrm{P}}=\mathrm{q}_{\mathrm{I}}^{\mathrm{P}}\left(\mathrm{p}^{\mathrm{p}}-\mathrm{c}_{\mathrm{I}}\right)-\mathrm{FC}_{\mathrm{I}} .
$$

Using the derived expressions for the equilibrium price and quantity for the incumbent leads to

$$
\Pi_{\mathrm{I}}^{\mathrm{P}}=\left(\frac{\mathrm{a}-\mathrm{c}_{\mathrm{E}}}{\mathrm{b}}-2 \sqrt{\mathrm{FC}_{\mathrm{E}} / \mathrm{b}}\right)\left(\left(\sqrt{\mathrm{FC}_{\mathrm{E}} \mathrm{b}}+\mathrm{c}_{\mathrm{E}}\right)-\mathrm{c}_{\mathrm{I}}\right)-\mathrm{FC}_{\mathrm{I}} .
$$

The profits of the entrant are (by model construction) given by

$$
\Pi_{\mathrm{E}}^{\mathrm{P}}=0 \text {. }
$$

Finally, the consumer surplus realised under predation can be calculated to

$$
\mathrm{CS}^{\text {Pred }}=\left(\mathrm{a}-\left(\sqrt{\mathrm{FC}_{\mathrm{E}} \mathrm{b}}+\mathrm{c}_{\mathrm{E}}\right)\right)\left(\left(\sqrt{\mathrm{FC}_{\mathrm{E}} / \mathrm{b}}\right)+\left(\frac{\mathrm{a}-\mathrm{c}_{\mathrm{E}}}{\mathrm{b}}-2 \sqrt{\mathrm{FC}_{\mathrm{E}} / \mathrm{b}}\right)\right]\left(\frac{1}{2}\right) .
$$

After specifying the welfare components for the three different market states (which are summed up in the following Table 1), the model specification can be applied to the different general enforcement options. The results are presented in Table 2. As the expressions in Table 2 are difficult to interpret, the following section applies a certain market specification in the form of certain demand and cost functions to allow an easier interpretation of the theoretical results. 
Table 1: Isolating the welfare effects of predation

\begin{tabular}{|c|c|c|c|}
\hline & Incumbent's profits & Entrant's profits & Consumer surplus \\
\hline Monopoly & $\frac{\left(a-c_{I}\right)^{2}}{4 b}-F C_{I}$ & 0 & $\frac{\left(a-c_{I}\right)^{2}}{8 b}$ \\
\hline Duopoly & $\frac{\left(a-2 c_{I}+c_{E}\right)^{2}}{9 b}-F C_{I}$ & $\frac{\left(a-2 c_{E}+c_{I}\right)^{2}}{9 b}-F_{E}$ & $\begin{array}{c}\left(a-\left(\frac{a+c_{I}+c_{E}}{3}\right)\right)\left[\left(\frac{a-2 c_{I}+c_{E}}{3 b}\right)+\right. \\
\left.\left(\frac{a-2 c_{E}+c_{I}}{3 b}\right)\right]\left(\frac{1}{2}\right)\end{array}$ \\
\hline Predation & $\begin{array}{l}\left(\frac{a-c_{E}}{b}-2 \sqrt{F C_{E} / b}\right) \times \\
\left(\left(\sqrt{F C_{E} b}+c_{E}\right)-c_{I}\right)-F C_{I}\end{array}$ & 0 & $\begin{array}{c}\left(\mathrm{a}-\left(\sqrt{\mathrm{FC}_{\mathrm{E}} \mathrm{b}}+\mathrm{c}_{\mathrm{E}}\right)\right)\left[\left(\sqrt{\mathrm{FC}_{\mathrm{E}} / \mathrm{b}}\right)+\right. \\
\left.\left(\frac{\mathrm{a}-\mathrm{c}_{\mathrm{E}}}{\mathrm{b}}-2 \sqrt{\mathrm{FC}_{\mathrm{E}} / \mathrm{b}}\right)\right]\left(\frac{1}{2}\right)\end{array}$ \\
\hline
\end{tabular}


Table 2: Predation enforcement options

\begin{tabular}{|c|c|c|}
\hline (1) & $\begin{array}{l}\text { Predation as a } \\
\text { rational } \\
\text { business } \\
\text { strategy }\end{array}$ & $\begin{array}{c}\alpha\left\{\left[\frac{\left(a-2 c_{I}+c_{E}\right)^{2}}{9 b}-F C_{I}\right]-\left[\left(\frac{a-c_{E}}{b}-2 \sqrt{F C_{E} / b}\right) \times\left(\left(\sqrt{F C_{E} b}+c_{E}\right)-c_{I}\right)-F C\right]\right\}< \\
\beta\left\{\left[\frac{\left(a-c_{I}\right)^{2}}{4 b}-F_{I}\right]-\left[\frac{\left(a-2 c_{I}+c_{E}\right)^{2}}{9 b}-F_{I}\right]\right\}\end{array}$ \\
\hline (2) & $\begin{array}{l}\text { Net welfare } \\
\text { increase } \\
\text { compared to } \\
\text { monopoly }\end{array}$ & $\begin{array}{l}\left.\left\{\left(a-\left(\sqrt{\mathrm{FC}_{\mathrm{E}} \mathrm{b}}+\mathrm{c}_{\mathrm{E}}\right)\right)\left(\sqrt{\mathrm{FC}_{\mathrm{E}} / \mathrm{b}}\right)+\left(\frac{\mathrm{a}-\mathrm{c}_{\mathrm{E}}}{\mathrm{b}}-2 \sqrt{\mathrm{FC}_{\mathrm{E}} / \mathrm{b}}\right)\right]\left(\frac{1}{2}\right)\right\}-\frac{\left(\mathrm{a}-\mathrm{c}_{\mathrm{I}}\right)^{2}}{8 \mathrm{~b}}> \\
{\left[\frac{\left(\mathrm{a}-\mathrm{c}_{\mathrm{I}}\right)^{2}}{4 \mathrm{~b}}-\mathrm{FC}\right]-\left[\left(\frac{\mathrm{a}-\mathrm{c}_{\mathrm{E}}}{\mathrm{b}}-2 \sqrt{\mathrm{FC}_{\mathrm{E}} / \mathrm{b}}\right) \times\left(\left(\sqrt{\mathrm{FC}_{\mathrm{E}} \mathrm{b}}+\mathrm{c}_{\mathrm{E}}\right)-\mathrm{c}_{\mathrm{I}}\right)-\mathrm{FC}_{\mathrm{I}}\right]}\end{array}$ \\
\hline (3) & $\begin{array}{l}\text { Predation } \\
\text { unsuccessful } \\
\text { (ex post I rule) } \\
\text { compared to } \\
\text { successful } \\
\text { predation (no } \\
\text { rule) }\end{array}$ & $\begin{array}{l}\left\{\left(a-\left(\frac{a+c_{I}+c_{E}}{3}\right)\right)\left[\left(\frac{a-2 c_{I}+c_{E}}{3 b}\right)+\left(\frac{a-2 c_{E}+c_{I}}{3 b}\right)\right]\right\}\left(\frac{1}{2}\right)-\frac{\left(a-c_{I}\right)^{2}}{8 b}> \\
\left(\frac{\left(a-c_{I}\right)^{2}}{4 b}-F C_{I}\right)-\left(\frac{\left(a-2 c_{I}+c_{E}\right)^{2}}{9 b}-F C_{I}\right)-\left(\frac{\left(a-2 c_{E}+c_{I}\right)^{2}}{9 b}-F C_{E}\right)\end{array}$ \\
\hline (4) & $\begin{array}{l}\text { Gain-based } \\
\text { fine }\end{array}$ & $\begin{array}{c}\beta\left\{\left(\frac{\left(a-c_{I}\right)^{2}}{4 b}-F C_{I}\right)-\left(\frac{\left(a-2 c_{I}+c_{E}\right)^{2}}{9 b}-F_{I}\right)\right\}+ \\
\alpha\left\{\left(\left(\frac{a-c_{E}}{b}-2 \sqrt{F C_{E} / b}\right) \times\left(\left(\sqrt{F C_{E} b}+c_{E}\right)-c_{I}\right)-F C_{I}\right]-\left(\frac{\left(a-2 c_{I}+c_{E}\right)^{2}}{9 b}-F C_{I}\right)\right\}\end{array}$ \\
\hline$(5)$ & $\begin{array}{l}\text { Harm-based } \\
\text { fine }\end{array}$ & $\begin{array}{l}\alpha\left\{\left(a-\left(\frac{a+c_{I}+c_{E}}{3}\right)\right)\left[\left(\frac{a-2 c_{I}+c_{E}}{3 b}\right)+\left(\frac{a-2 c_{E}+c_{I}}{3 b}\right)\right]\left(\frac{1}{2}\right)-\left(a-\left(\sqrt{F C_{E} b}+c_{E}\right)\right)\left(\left(\sqrt{F C_{E} / b}\right)+\right.\right. \\
\left.\left.\left(\frac{a-c_{E}}{b}-2 \sqrt{F C_{E} / b}\right)\right]\left(\frac{1}{2}\right)+\frac{\left(a-2 c_{E}+c_{I}\right)^{2}}{9 b}-F C_{E}\right\}+\beta\left\{\left(a-\left(\frac{a+c_{I}+c_{E}}{3}\right)\right)\left[\left(\frac{a-2 c_{I}+c_{E}}{3 b}\right)+\right.\right.\end{array}$ \\
\hline
\end{tabular}




\begin{tabular}{|c|c|c|}
\hline & & $\left.\left.\left(\frac{a-2 c_{E}+c_{I}}{3 b}\right)\right]\left(\frac{1}{2}\right)-\frac{\left(a-c_{I}\right)^{2}}{8 b}+\frac{\left(a-2 c_{E}+c_{I}\right)^{2}}{9 b}-F_{E}\right\}$ \\
\hline (6) & $\begin{array}{l}\text { Ex post I } \\
\text { versus } \\
\text { ex post II }\end{array}$ & $\begin{array}{c}(\beta-\varepsilon)\left\{\left(a-\left(\frac{a+c_{I}+c_{E}}{3}\right)\right)\left[\left(\frac{a-2 c_{I}+c_{E}}{3 b}\right)+\left(\frac{a-2 c_{E}+c_{I}}{3 b}\right)\right]\left(\frac{1}{2}\right)-\frac{\left(a-c_{I}\right)^{2}}{8 b}\right\}- \\
\alpha\left\{\left(a-\left(\frac{a+c_{I}+c_{E}}{3}\right)\right)\left[\left(\frac{a-2 c_{I}+c_{E}}{3 b}\right)+\left(\frac{a-2 c_{E}+c_{I}}{3 b}\right)\right]\left(\frac{1}{2}\right)-\left(\left(a-\left(\sqrt{F C_{E} b}+c_{E}\right)\right)\left[\left(\sqrt{F C_{E} / b}\right)+\left(\frac{a-c_{E}}{b}-2 \sqrt{F C_{E} / b}\right)\right]\left(\frac{1}{2}\right)\right)\right\}>\beta\left\{\frac{\left(a-c_{I}\right)^{2}}{4 b}-F C_{I}-\right. \\
\left.\frac{\left(a-2 c_{E}+c_{I}\right)^{2}}{9 b}-F C_{E}-\frac{\left(a-2 c_{I}+c_{E}\right)^{2}}{9 b}-F C_{I}\right\}+(\alpha+\varepsilon)\left(\frac{\left(a-2 c_{E}+c_{I}\right)^{2}}{9 b}-F C_{E}\right)\end{array}$ \\
\hline (7) & $\begin{array}{l}\text { Ex ante vs. } \\
\text { ex post I }\end{array}$ & $\begin{array}{c}\left(a-\left(\frac{a+c_{I}+c_{E}}{3}\right)\right)\left[\left(\frac{a-2 c_{I}+c_{E}}{3 b}\right)+\left(\frac{a-2 c_{E}+c_{I}}{3 b}\right)\right]\left(\frac{1}{2}\right)-\left\{\left(a-\left(\sqrt{F C_{E} b}+c_{E}\right)\right)\left(\sqrt{F C_{E} / b}\right)+\right. \\
\left.\left.\left(\frac{a-c_{E}}{b}-2 \sqrt{F C_{E} / b}\right)\right]\left(\frac{1}{2}\right)\right\}>\left(\frac{a-c_{E}}{b}-2 \sqrt{F C_{E} / b}\right) \times\left(\left(\sqrt{F C_{E} b}+c_{E}\right)-c_{I}\right)-F C_{I} \\
-\frac{\left(a-2 c_{E}+c_{I}\right)^{2}}{9 b}-F C_{E}-\frac{\left(a-2 c_{I}+c_{E}\right)^{2}}{9 b}-F C_{I}\end{array}$ \\
\hline
\end{tabular}




\subsection{Market specification and applied results}

Given the derivation of the general results in the preceding section, this section will specify the market under investigation and therefore allows the derivation of applied results. To be as specific as possible, it is assumed that market demand is given by $Q=1,000-1,000 p$ (which is equivalent to an inverse demand function of $\left.p=1-0.001\left(q_{1}+q_{2}\right)\right)$. The marginal costs of the incumbent are fixed to $c_{\mathrm{I}}=0.28$. However, the entrant's marginal costs are subject to change. In scenario 1, the entrant is equally efficient and therefore has constant marginal costs of $c_{E}=0.28$. In scenario 2 , the entrant has marginal costs of $c_{E}=0.21$ and therefore a moderate cost advantage over the incumbent. In scenario 3 , the entrant has a large cost advantage leading to constant marginal costs of $c_{E}=0.14$. With respect to fixed cost, two different states are differentiated in all three scenarios: $F C_{I}=F C_{E}=0$ and $F C_{I}=F C_{E}=10$. Finally, within every entry scenario, four different lengths of the post-predation period $(\beta)$ are assumed: while $\alpha$ is fixed to $\alpha=5, \beta$ has the four specifications $\beta=5, \beta=7, \beta=10$ and $\beta=15$. These scenario specifications are summed up in Table 3.

Table 3: Scenario specifications

\begin{tabular}{lccccc}
\hline & $\begin{array}{c}\text { Marginal costs } \\
\text { (Incumbent) }\end{array}$ & $\begin{array}{c}\text { Marginal costs } \\
\text { (Entrant) }\end{array}$ & $\begin{array}{c}\text { Fixed costs } \\
\text { (Incumbent } \\
\text { and entrant) }\end{array}$ & $\begin{array}{c}\text { Predation } \\
\text { periods } \alpha\end{array}$ & $\begin{array}{c}\text { Post-predation } \\
\text { periods } \beta\end{array}$ \\
\hline Scenario 1 & 0.28 & 0.28 & $0 ; 10$ & 5 & $5 ; 7 ; 10 ; 15$ \\
Scenario 2 & 0.28 & 0.21 & $0 ; 10$ & 5 & $5 ; 7 ; 10 ; 15$ \\
Scenario 3 & 0.28 & 0.14 & $0 ; 10$ & 5 & $5 ; 7 ; 10 ; 15$ \\
\hline
\end{tabular}

In the following, the three scenarios are first characterised through an initial welfare assessment in Section 3.2.1, followed by an assessment of market prices in Section 3.2.2. The evaluation of selected predation enforcement options is subsequently provided in Section 3.2.3.

\subsubsection{Initial welfare assessment}

Given the market and scenario specifications, it is possible first to calculate consumer surplus, producer surplus and overall welfare of the three possible market states: monopoly, duopoly and predation. The following Figures 2, 3 and 4 show the results for the three scenarios. ${ }^{11}$ In scenario 1 , the monopolistic producer realises a relatively high profit while the consumers get a relatively small consumer surplus. In the duopoly situation, the consumer surplus increases significantly while overall producer surplus drops and is equally shared between the incumbent and the entrant. In the predation situation, the entrant (by construction) and the incumbent make zero profits. The consumer surplus is relatively high and equal to the overall welfare. ${ }^{12}$ The introduction of fixed costs does not change the picture much. In the monopoly situation, the consumer surplus is the same while the producer surplus is reduced by the amount of fixed costs. The same is basically true for the duopoly situation. In the predation state, the incumbent is able to drive down the entrant's profits to zero and still realises a small positive profit. Total welfare is still substantially higher than in the duopoly case, but it is smaller than in the case without fixed costs.

\footnotetext{
11 The overall welfare is represented by the positive height of the boxes; if the producer surplus is negative, it has been subtracted from the consumer surplus for presentational purposes.

12 In fact, it can be shown that the consumer surplus is equal to the surplus realised under perfect competition.
} 

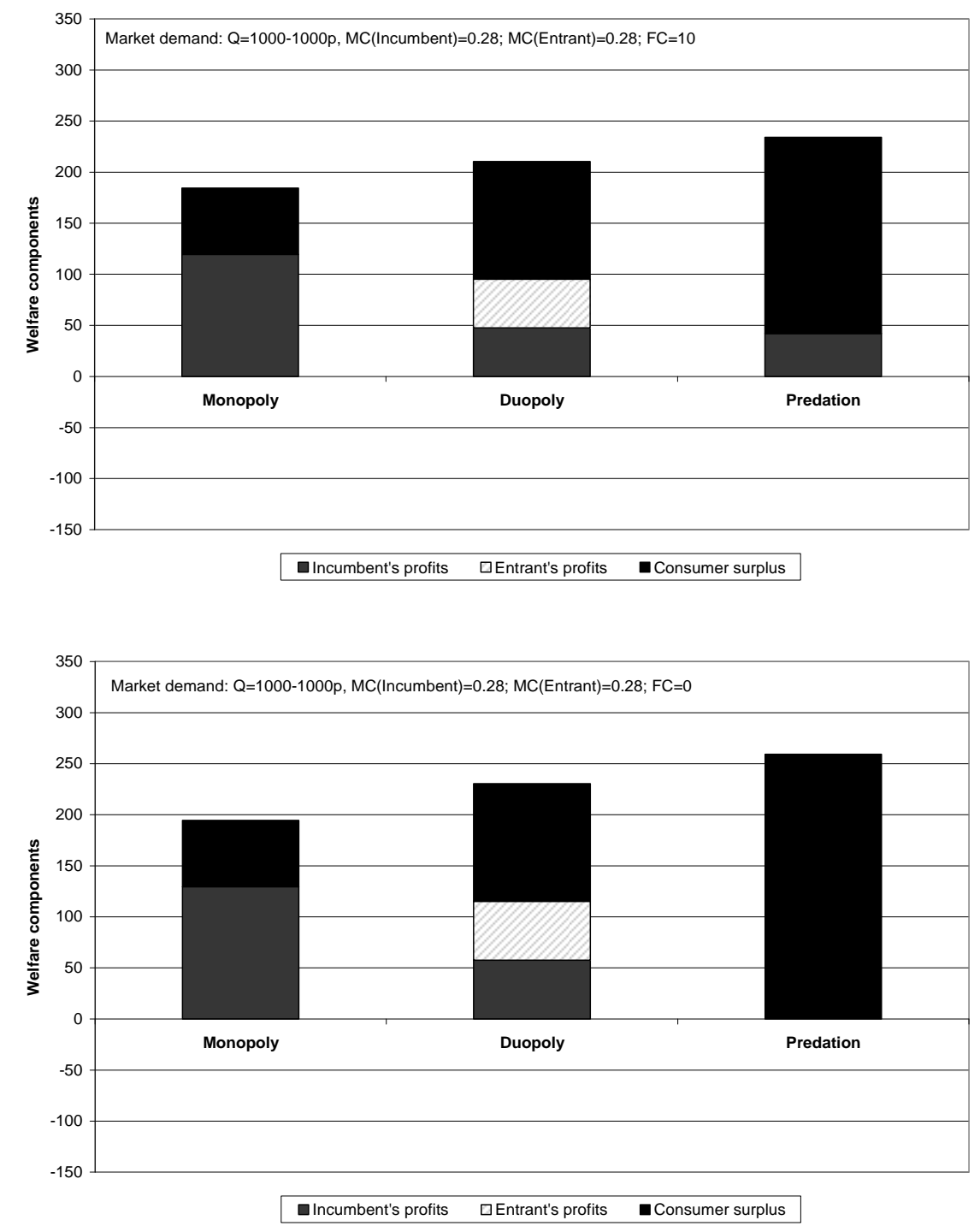

Figure 2: Welfare components if entrant has no cost advantage (Scenario 1)

In scenario 2 , the monopoly situation remains unchanged compared to scenario 1 . In the duopoly situation without fixed costs, the cost advantage of the entrant leads to a higher duopoly total welfare, slightly higher consumer surplus and producer surplus. As the entrant has an efficiency advantage over the incumbent, it now gets a larger share of the producer surplus. In the predation period, the incumbent now has to accept losses in order to drive down the entrant's profits to zero. While the consumer surplus is unchanged, compared to scenario 1, overall welfare drops by the amount of the negative producer surplus. Considering fixed costs basically has the same effects as described above. Monopoly and duopoly profits decline by the amount of the fixed cost, which directly feeds into a loss in overall welfare. In the predation situation, the incumbent can drive down the profit of the entrant to zero and still realises a small but positive producer surplus. 

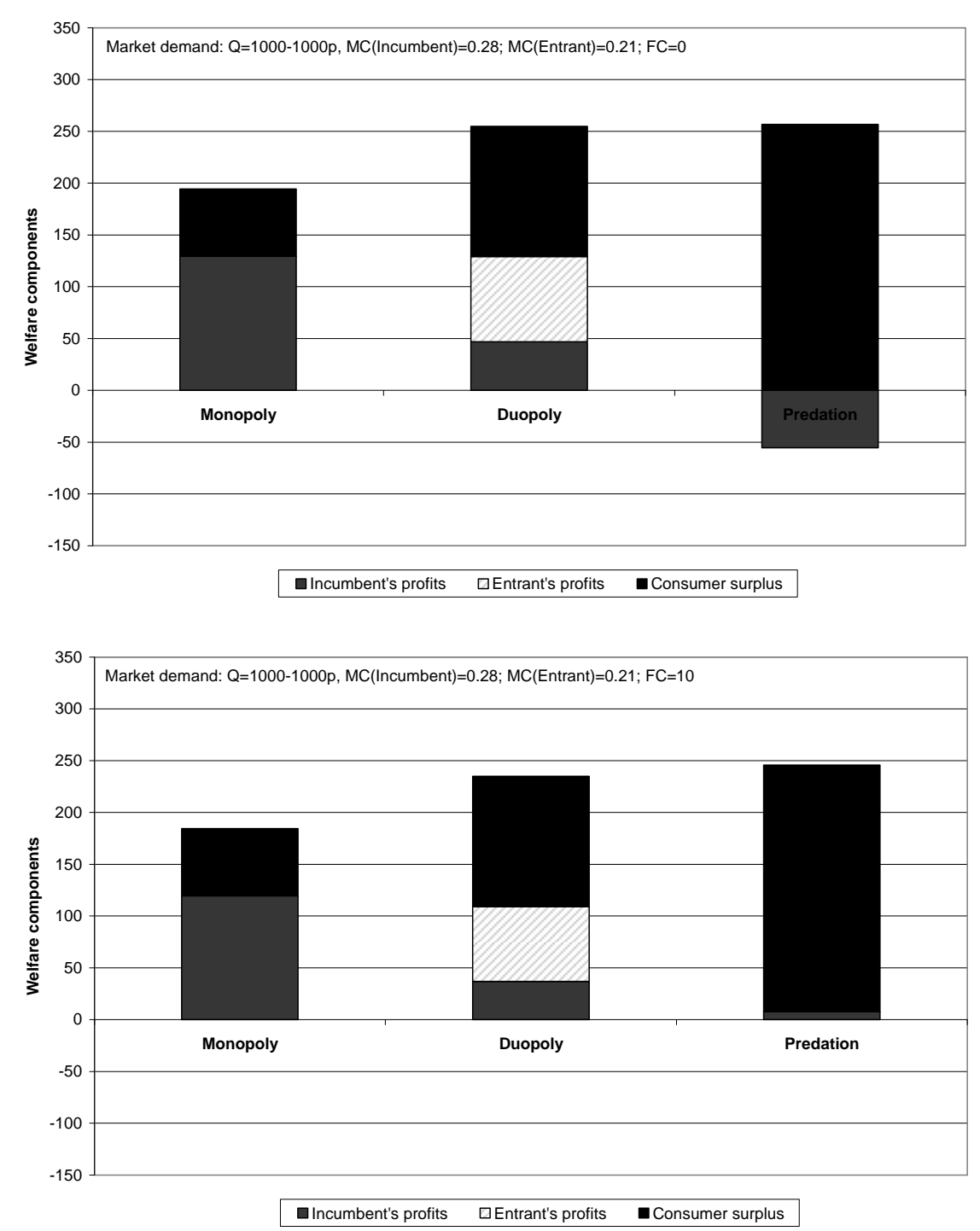

Figure 3: Welfare components if entrant has moderate cost advantage (Scenario 2)

In scenario 3, the monopolist situation remains unchanged. The effects in the duopoly and predation situation are the same as described in scenario 2 , but the effects are more distinctive due to the larger efficiency advantage of the entrant. Overall welfare in the duopoly and predation situations increases moderately. In the predation situation, the incumbent realises an even larger negative producer surplus, which leads to a reduction in welfare of the same size. Even in the state with positive fixed costs, the incumbent is still realising negative profits in the predation state. 

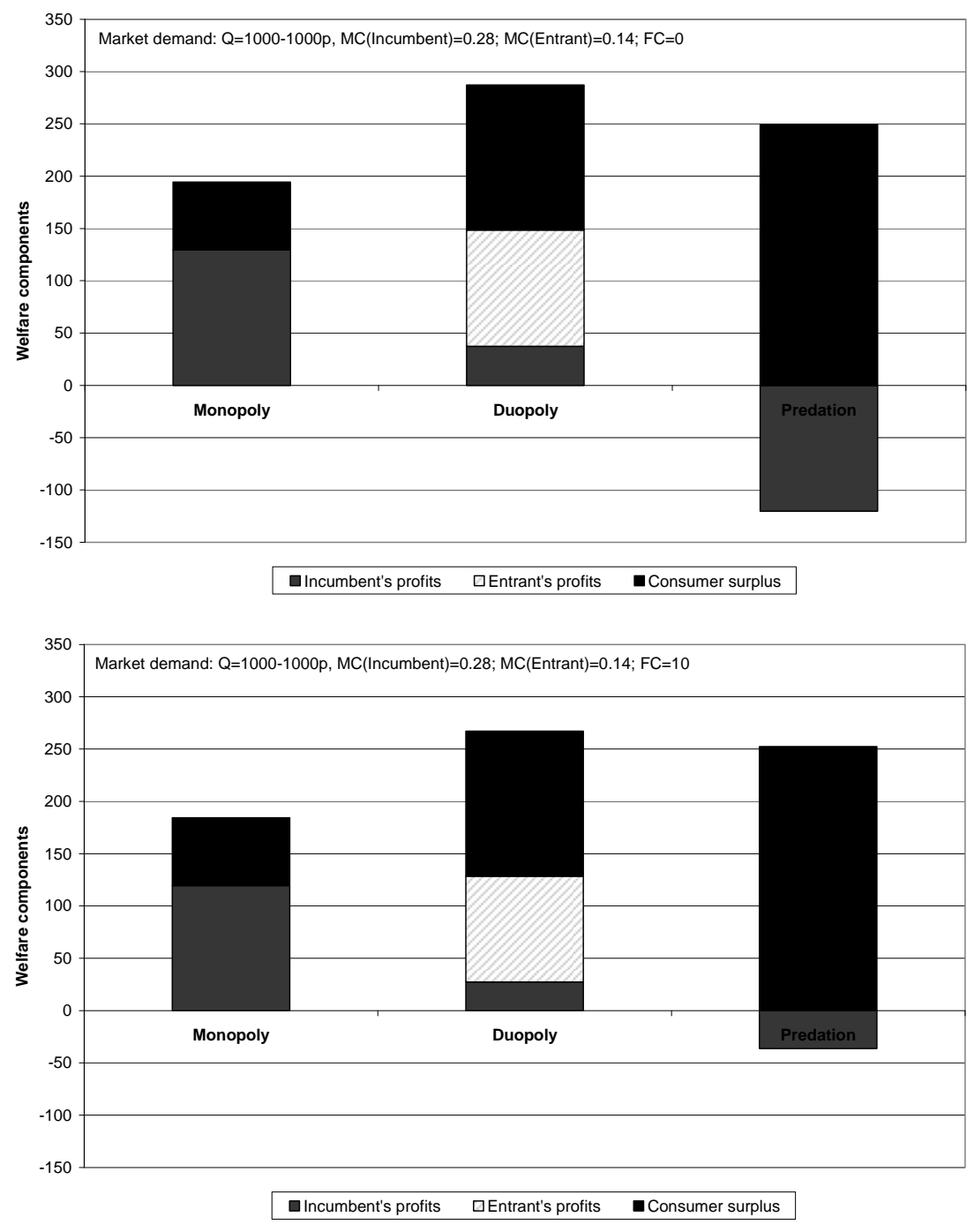

Figure 4: Welfare components if entrant has large cost advantage (Scenario 3)

\subsubsection{Analysis of market prices}

In addition to an analysis of the welfare components for the different scenarios, a look at the resulting market prices predicted by the model is insightful. These prices are depicted for the different market states in Table 4. As explained above, the marginal costs of the incumbent are always given by 0.28 , while the entrant can have no, a moderate or a large cost advantage. 
Table 4: Market prices for the different market structures

\begin{tabular}{llccc}
\hline & $\begin{array}{l}\text { Cost } \\
\text { Advantage }\end{array}$ & $\mathrm{FC}=0$ & $\mathrm{FC}=10$ & $\mathrm{FC}=20$ \\
\hline Monopoly & & 0.64 & 0.64 & 0.64 \\
\multirow{3}{*}{ Duopoly } & & & \\
& No & 0.52 & 0.52 & 0.52 \\
& Moderate & 0.50 & 0.50 & 0.50 \\
& Large & 0.47 & 0.47 & 0.47 \\
\multirow{3}{*}{ Predation } & & & 0.42 \\
& No & 0.28 & 0.38 & 0.35 \\
& Moderate & $\mathbf{0 . 2 1}$ & 0.31 & 0.28 \\
\hline
\end{tabular}

As Table 4 shows, the incumbent does not always have to drop prices below its own marginal costs to force the entrant out of the market. In the case of equal marginal costs, the incumbent's prices are always at or above its marginal costs. If the entrant has a moderate cost advantage, the incumbent's prices are below its own marginal costs in a world without fixed costs; however, as the table shows, in a world of $\mathrm{FC}=10$, the incumbent can still predate with a price above its own marginal cost. If the entrant has a large cost advantage, the incumbent has to accept prices below its marginal costs even in a world of $\mathrm{FC}=10$. However, if $\mathrm{FC}=20$ he can force the exit of the entrant with prices at his own marginal costs. ${ }^{13}$ These theoretically derived market prices which are sufficient to drive the entrant out of the market illustrate the fuzziness and consequently weak performance of any application of the Areeda-Turner rule in detecting predation.

\subsubsection{Assessment of predation enforcement options}

Following the set-up and characterisation of the basic model of competitive interaction, the next step is to connect these results to the general enforcement options derived above. In the following, a perfect world is assumed, i.e. antitrust enforcement is costless and the antitrust authority acts faultlessly. It is then possible to quantify the following conditions for the chosen market specification (see Table 2 for the general derivations):

1. Predation as a rational business strategy (i.e. it must be profitable for the incumbent),

2. Welfare increases if predation is successful (compared to a continuation of monopoly),

3. Welfare increases if predation is unsuccessful (compared to a successful predation attempt) or - alternatively - whether an ex post I rule leads to a welfare increase compared to a no rule approach,

4. Level of an optimal gain-based fine (including the percentage value of the monopoly profit in the preceding year),

5. Level of an optimal harm-based fine (including the percentage value of the monopoly profit in the preceding year),

6. Ex post I enforcement leads to higher welfare than ex post II enforcement,

7. Ex ante enforcement leads to a higher welfare than ex post I enforcement.

13 For $\mathrm{FC}=0$, the incumbent has to match the marginal costs of the entrant to reach its exit. Overall, the table in combination with the welfare components analysis above reflects the well-known theoretical result that low prices are necessarily good for consumers as they increase consumer welfare, but are not necessarily good for overall welfare. In the model and market specification used above, the incumbent has to accept prices below its own marginal costs on three occasions to reach the exit of the entrant: $\mathrm{FC}=0$ / moderate, $\mathrm{FC}=0$ / large and $\mathrm{FC}=10$ / large. While consumer welfare always increases in the predation situation, compared to the duopoly situation, total welfare is slightly higher in the $\mathrm{FC}=0 /$ moderate scenario and clearly smaller in the remaining two worlds with a large cost advantage. 
The quantitative results for all seven conditions can be found in Table 5. The derivation of the delta values for the various options can be exemplified for condition (2). As shown above, this condition is met as long as

$$
\mathrm{CS}^{\text {Pred }}-\mathrm{CS}^{\text {Mono }}>\pi_{\mathrm{I}}^{\text {Mono }}-\left(\pi_{\mathrm{E}}^{\text {Pred }}+\pi_{\mathrm{I}}^{\text {Pred }}\right) .
$$

Rewriting the equation leads to

$$
\mathrm{CS}^{\text {Pred }}-\mathrm{CS}^{\text {Mono }}-\pi_{\mathrm{I}}^{\text {Mono }}+\pi_{\mathrm{E}}^{\text {Pred }}+\pi_{\mathrm{I}}^{\text {Pred }}>0 .
$$

or short $\Delta>0$. This delta value is presented in Table 5 (multiplied by the relevant number of periods $\alpha$ and $\beta$ ). The deltas for the other conditions are derived in the same way.

In the first column of Table 5, it is specified whether predation is a rational business strategy for the given market specification. As it was argued above, the profits in the postpredation period must be higher than the losses in the predation period to make predation a rational strategy. Formally, the condition can be expressed as follows:

$$
\alpha\left(\pi^{\text {Duo }}-\pi^{\text {Pred }}\right)<\beta\left(\pi^{\text {Mono }}-\pi^{\text {Duo }}\right) .
$$

The values in the first column in Table 5 show that if the entrant has the same marginal costs as the incumbent, predation is always a rational strategy for the incumbent. This is true even for the case that the post-predation period 'only' has the same length as the predation period. However, if the entrant has a moderate cost advantage, predation becomes an irrational strategy if $\alpha=\beta=5$ (indicating that it is profit-maximising for the incumbent to accommodate), but remains rational for $\beta=7,10$ and 15. Finally, if the entrant has a large cost advantage, predation becomes irrational for $\alpha, \beta=5$ and 7 but stays rational for $\beta=10$ and 15 . It can be concluded that the more efficient the entrant, the larger the post-predation period must be in order to make predation a rational strategy. Furthermore, the existence of fixed costs generally makes the use of predation a more successful strategy for the incumbent. 
Table 5. Delta values for Scenarios 1, 2 and 3

\begin{tabular}{|c|c|c|c|c|c|c|c|c|}
\hline & 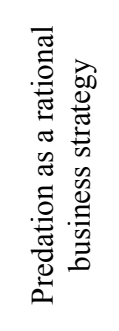 & 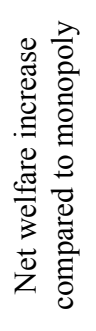 & 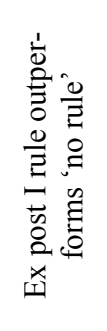 & 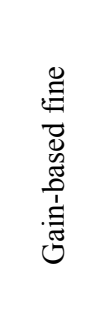 & 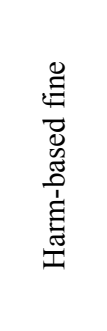 & 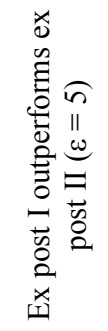 & 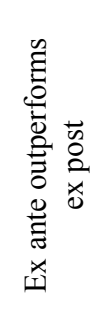 & 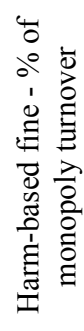 \\
\hline & (1) & (2) & (3) & (4) & (5) & (6) & (7) & \\
\hline & $\Delta<0$ & $\Delta>0$ & $\Delta>0$ & $\Delta>0$ & $\Delta>0$ & $\Delta>0$ & $\Delta>0$ & \\
\hline \multicolumn{9}{|l|}{$\begin{array}{l}\text { Scenario 1-Same } \\
\text { marginal cost }\end{array}$} \\
\hline \multicolumn{9}{|l|}{$a=5, b=5$} \\
\hline No fixed cost & -72.0 & 324.0 & 180.0 & 72.0 & 108.0 & 72.0 & -144.0 & $4 \%$ \\
\hline 10 per firm & -332.0 & 249.0 & 130.0 & 332.0 & 343.0 & -213.0 & -119.0 & $12 \%$ \\
\hline \multicolumn{9}{|l|}{$a=5, b=7$} \\
\hline No fixed cost & -216.0 & 324.0 & 252.0 & 216.0 & 324.0 & 144.0 & -144.0 & $12 \%$ \\
\hline 10 per firm & -476.0 & 249.0 & 182.0 & 476.0 & 539.0 & -161.0 & -119.0 & $19 \%$ \\
\hline \multicolumn{9}{|l|}{$a=5, b=10$} \\
\hline No fixed cost & -432.0 & 324.0 & 360.0 & 432.0 & 648.0 & 252.0 & -144.0 & $23 \%$ \\
\hline 10 per firm & -692.0 & 249.0 & 260.0 & 692.0 & 833.0 & -83.0 & -119.0 & $30 \%$ \\
\hline \multicolumn{9}{|l|}{$a=5, b=15$} \\
\hline No fixed cost & -792.0 & 324.0 & 540.0 & 792.0 & 1188.0 & 432.0 & -144.0 & $43 \%$ \\
\hline 10 per firm & -1052.0 & 249.0 & 390.0 & 1052.0 & 1323.0 & 47.0 & -119.0 & $48 \%$ \\
\hline \multicolumn{9}{|c|}{\begin{tabular}{l|l} 
Scenario 2-Entrant & \\
has moderate cost \\
advantage
\end{tabular}} \\
\hline \multicolumn{9}{|l|}{$a=5, b=5$} \\
\hline No fixed cost & 97.9 & 311.8 & 302.8 & -97.9 & 196.0 & 106.9 & -8.9 & $7 \%$ \\
\hline 10 per firm & -267.1 & 306.8 & 252.8 & 267.1 & 466.0 & -213.0 & -54.0 & $17 \%$ \\
\hline \multicolumn{9}{|l|}{$a=5, b=7$} \\
\hline No fixed cost & -67.4 & 311.8 & 423.9 & 67.4 & 482.4 & 228.0 & -8.9 & $17 \%$ \\
\hline 10 per firm & -432.4 & 306.8 & 353.9 & 432.4 & 732.4 & -112.0 & -54.0 & $26 \%$ \\
\hline \multicolumn{9}{|l|}{$a=5, b=10$} \\
\hline No fixed cost & -315.4 & 311.8 & 605.6 & 315.4 & 912.1 & 409.7 & -8.9 & $33 \%$ \\
\hline 10 per firm & -680.4 & 306.8 & 505.6 & 680.4 & 1132.1 & 39.7 & -54.0 & $41 \%$ \\
\hline \multicolumn{9}{|l|}{$a=5, b=15$} \\
\hline No fixed cost & -728.7 & 311.8 & 908.4 & 728.7 & 1628.2 & 712.5 & -8.9 & $59 \%$ \\
\hline 10 per firm & -1093.7 & 306.8 & 758.4 & 1093.7 & 1798.2 & 292.5 & -54.0 & $65 \%$ \\
\hline \multicolumn{9}{|c|}{\begin{tabular}{l|l} 
Scenario 3 -Entrant & \\
has large cost & \\
advantage &
\end{tabular}} \\
\hline \multicolumn{9}{|l|}{$a=5, b=5$} \\
\hline No fixed cost & 327.7 & 275.0 & 463.9 & -327.7 & 325.1 & 138.8 & 188.9 & $12 \%$ \\
\hline 10 per firm & -142.3 & 340.0 & 413.9 & 142.3 & 630.1 & -216.2 & 73.9 & $23 \%$ \\
\hline \multicolumn{9}{|l|}{$a=5, b=7$} \\
\hline No fixed cost & 143.2 & 275.0 & 649.5 & -143.2 & 695.1 & 324.4 & 188.9 & $25 \%$ \\
\hline 10 per firm & -326.8 & 340.0 & 579.5 & 326.8 & 980.1 & -50.6 & 73.9 & $35 \%$ \\
\hline \multicolumn{9}{|l|}{$a=5, b=10$} \\
\hline No fixed cost & -133.5 & 275.0 & 927.8 & 133.5 & 1250.2 & 602.7 & 188.9 & $45 \%$ \\
\hline 10 per firm & -603.5 & 340.0 & 827.8 & 603.5 & 1505.2 & 197.7 & 73.9 & $54 \%$ \\
\hline \multicolumn{9}{|l|}{$a=5, b=15$} \\
\hline No fixed cost & -594.6 & 275.0 & 1391.7 & 594.6 & 2175.2 & 1066.6 & 188.9 & $79 \%$ \\
\hline 10 per firm & -1064.6 & 340.0 & 1241.7 & 1064.6 & 2380.2 & 611.6 & 73.9 & $86 \%$ \\
\hline
\end{tabular}


In the second column, it is tested whether a successful predation attempt leads to a net welfare increase compared to a continuation of monopoly. As Table 5 shows, this is the case in every scenario and every specification of $\beta$. The economic reason behind this finding is basically that the gain in consumer surplus in the predation period is higher than the corresponding losses in producer surplus.

In the third column, it is tested whether making predation unsuccessful increases welfare compared to a situation in which predation is successful. Formally, this is equal to the question if an ex post I rule outperforms a no rule approach. As the table shows, this is the case in every scenario. In other words, optimal antitrust enforcement has the potential to increase welfare in every scenario under the chosen model and market specification.

In the fourth column, the optimal gain-based fine is calculated. The fine is always positive except for the cases in which predation is an irrational strategy for the incumbent. The fine increases with $\beta$ (as the gain increases with $\beta$ ). The existence of fixed cost - ceteris paribus generally leads to a significant increase in the size of the optimal gain-based fine.

In the fifth column, the optimal harm-based fine is calculated. All values show positive fines indicating that predation is harmful in any case analysed. ${ }^{14}$ The harm-based fine is always larger than the corresponding gain-based fine. Furthermore, the harm-based fine increases with the efficiency of the entrant, indicating that the loss of a more efficient firm due to predation harms society more than the loss of an equally efficient firm.

In the sixth column, it is tested whether the switch from an ex post II rule (with an optimal harm-based fine after $\varepsilon=5$ post-predation enforcement periods) to an ex post I rule can lead to a welfare improvement. In general, the results show that as long as the fixed costs are equal to zero, it is always welfare-improving to trade an ex post I approach for an ex post II approach. The size of the welfare improvement rises with $\beta$ and the efficiency of the entrant. This can be explained by the fact that $\varepsilon=5$ and that the period of monopoly after punishment $(\beta-\varepsilon)$ increases, causing harm to society. The harm to society is increasing with the efficiency of the vanished entrant. If fixed costs of 10 are necessary to enter the market, it is often better to stay with an ex post II approach. As column six shows, if the entrant has the same efficiency, the welfare differential is negative for $\beta=5 ; 7 ; 10$. If the entrant is more efficient than the incumbent, the welfare differential remains negative for $\beta=5 ; 7$, indicating that it is welfareimproving to stay with an ex post II approach.

In the seventh column, it is tested whether an ex ante enforcement rule outperforms an ex post enforcement rule. As the column shows, this is not the case for scenarios 1 and 2 . However, if the entrant has a large cost advantage, an ex ante rule indeed outperforms an ex post rule. This is basically because under an ex post regime, the producer surplus losses incurred by the predation strategy of the (inefficient) incumbent are bigger than the additional consumer surplus created in the predation period.

In the last column, the percentage shares of the harm-based fines with respect to the monopoly turnover in the preceding business year are calculated. ${ }^{15}$ Compared to the maximum possible fine in the EU of $10 \%$ of the (worldwide) turnover, the percentages appear relatively high, especially for large beta values and the 'more efficient entrant' scenarios. This gives an indication that the largest fines possible in the European Union are unlikely to reach a full deterrence effect or can compensate for the harm caused by a predation strategy.

Based on the spreadsheet calculations undertaken to derive the pair-wise welfare comparisons shown in Table 5, it is further possible to characterise the welfare consequences

\footnotetext{
14 However, it is possible to show that the optimal harm-based fine turns negative for large $\alpha$ and small $\beta$. This basically reflects the fact that the incumbent invests a relatively large amount during the predation period $\alpha$ and does not have the chance to realise a positive return on investment in the short post-predation period $\beta$.

15 The monopoly turnover is 2764.8 .
} 
of selected iterative changes in the enforcement options graphically. This is done in Figures 5 and 6. Both figures include four charts depicting:

1. Welfare change due to switch from no rule to ex post I rule,

2. Welfare change due to switch from ex post II to ex post I,

3. Welfare change due to switch from ex post I to ex ante,

4. Aggregated welfare change due to predation enforcement.

Both figures differentiate only with respect to the underlying number of post-predation periods. While the charts in Figure 5 are based on $\beta=7$, Figure 6 assumes $\beta=15$. In line with the findings in Table 5, it is shown that a switch from a no rule approach to an ex post I approach is always welfare-increasing, irrespective of the underlying $\beta$-value (although the welfare change as well as the efficiency of the entrant increases in $\beta$ ).

In the case of a switch from ex post II to ex post I - depicted in the second chart in Figure 5 - it is shown that $\beta$ now becomes decisive with respect to the sign of the change in welfare. If $\beta$ is sufficiently small, the welfare change is negative (as shown for the case of $\beta=7$ ); otherwise it is positive (as shown for the case $\beta=15$ ). Furthermore, the charts in Figures 5 and 6 reveal that the welfare loss/gain is decreasing or increasing with the efficiency of the entrant, respectively.

If there is a switch from an ex post I to an ex ante approach, the figures show that the results do not depend on $\beta$. As explained above, such a switch in the enforcement option is only desirable from a total welfare perspective as long as the efficiency advantage is substantial (and the losses of the predator are correspondingly large).

Finally, Chart 4 in Figures 5 and 6 shows the aggregate welfare change due to predation enforcement. A comparison of both charts reveals that a no rule approach in both cases realises the lowest welfare change due to predation enforcement. In terms of the other enforcement options, the picture is more diverse. For the case of $\beta=7$, it is shown that an ex post II approach is welfare-maximising if the incumbent and the entrant have the same marginal costs. This result holds for the case of a moderate cost advantage on the side of the entrant. If, however, the entrant has a large efficiency advantage, it is shown that an ex ante approach would realise the largest increase in welfare.

The pattern just described for $\beta=7$ changes significantly if $\beta=15$ is assumed. Now an ex post I approach would maximise welfare in a world in which incumbent and entrant are equally efficient. The same conclusion holds for a moderate cost advantage on the side of the entrant. If, however, the entrant has a large efficiency advantage, an ex ante approach again becomes the welfare-maximising enforcement option. It is further worth remarking that the performance of an ex post II approach deteriorates significantly with the increase in $\beta$. While in the $\beta=7$ world, all three active enforcement options realise comparable levels of welfare increase, the $\beta=15$ world shows that only the ex post I and ex ante approaches are still comparable with respect to their respective welfare improvements. 


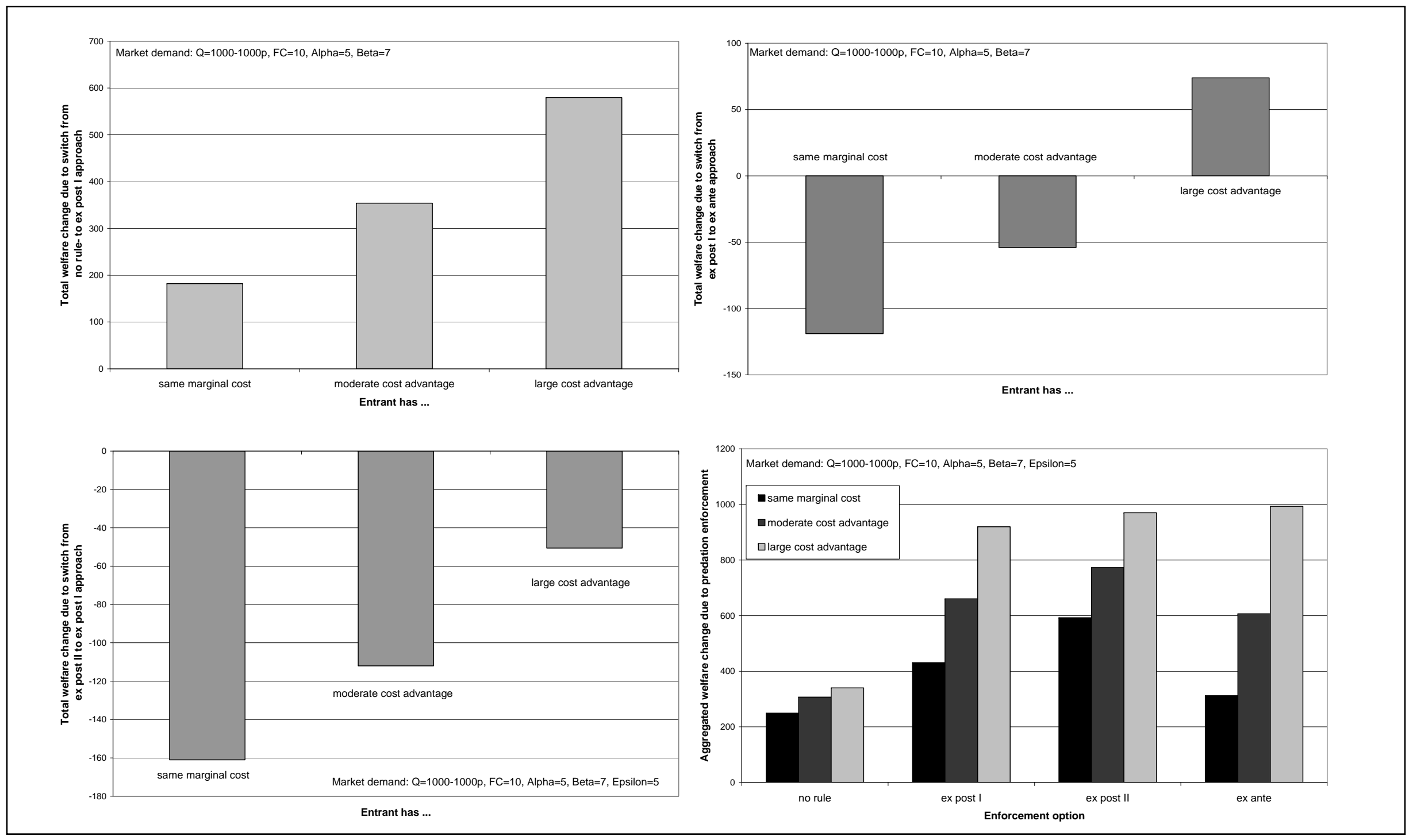

Figure 5: Welfare changes and aggregated welfare change for different enforcement options $(\alpha=5, \beta=7)$ 


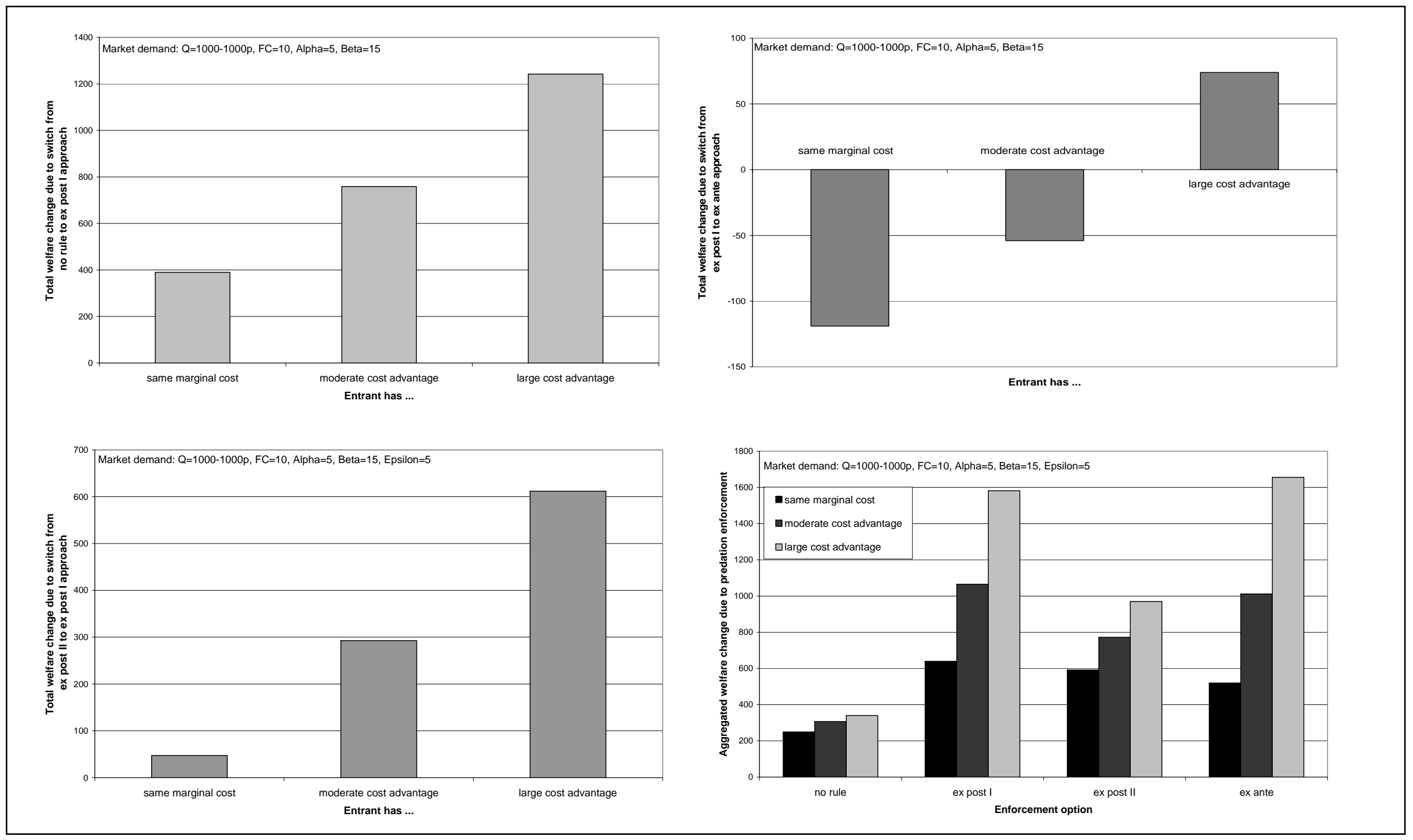

Figure 6: Welfare changes and aggregated welfare change for different enforcement options $(\alpha=5, \beta=15)$ 


\section{Summary and conclusion}

The major interest of antitrust law and economics with respect to predation strategies has been largely twofold. On the one hand, there has been a lively discussion on the question whether predation can be a rational strategy for an incumbent facing an entry threat. On the other hand, research has focused on the problem of how an antitrust authority could and should detect predation strategies and, especially how it could distinguish such abuses from socially desirable procompetitive behaviour. The aim of this paper was to think beyond these two standard stages of rationality and detection and to focus on a third one in the antitrust analysis of predation: intervention. This stage acknowledges the necessity of appropriate detection rules for efficient predation enforcement but goes beyond these insights, using them as input for determining how these rules should be linked to interventions against predation strategies.

Against this background, the paper commenced with a brief characterisation of the building blocks of a framework to enforce anti-predation rules and subsequently evaluated selected enforcement options in a Cournot-type duopoly predation model. Differentiating between a no rule approach, an ex ante approach and two ex post approaches, Table 6 summarises the key results of the analysis.

Table 6: Results of an evaluation of predation enforcement options

\begin{tabular}{|c|c|}
\hline $\begin{array}{l}\text { Enforcement } \\
\text { Option }\end{array}$ & Key simulation results \\
\hline No rule & $\begin{array}{l}\text { - Superior to a simple continuation of monopoly, as consumers typically gain more in } \\
\text { the predation period than producers lose (in terms of surplus) } \\
\text { - Inferior to any kind of antitrust enforcement (in a perfect world) } \\
\text { - Only exceptions are cases in which entry is socially inefficient (such as in a natural } \\
\text { monopoly or during patent protection to secure innovation incentives) }\end{array}$ \\
\hline \multirow[t]{2}{*}{$\begin{array}{l}\text { Ex post rule of } \\
\text { reason }\end{array}$} & $\begin{array}{l}\text { - Differentiates between ex post I enforcement (while entrant is in the market) and ex } \\
\text { post II enforcement (entrant had to leave the market) } \\
\text { - Ex post I approach is typically superior to a no rule approach } \\
\text { - In an ex post I approach the antitrust authority has to terminate the infringement } \\
\text { (restoring competition) but should not impose a fine, as the incumbent has already } \\
\text { fined itself by investing in a predation strategy without any positive payoff } \\
\text { - An ex post I approach always dominates an ex post II approach in a world without } \\
\text { fixed costs. In a world with fixed costs, the ex post I approach is more likely to be } \\
\text { superior to an ex post II approach the longer the post-predation period and the more } \\
\text { efficient the entrant is }\end{array}$ \\
\hline & $\begin{array}{l}\text { - An ex post II approach uses fines to take away the gain of the predation strategy or } \\
\text { alternatively to compensate for the harm the predation strategy caused to others } \\
\text { - In an ex post II approach, the antitrust authority does not have to end the } \\
\text { infringement but has to impose a fine which should be a function of the length of the } \\
\text { predation period, the length of the post-predation period and the efficiency of the } \\
\text { entrant } \\
\text { - Harm-based fines are found to have certain advantages over gain-based fines; } \\
\text { typically, harm-based fines are larger than gain-based fines, indicating that a } \\
\text { deterrence effect is always reached with optimal harm-based fines } \\
\text { - Possible fine levels in the EU are unlikely to have a deterrence effect }\end{array}$ \\
\hline Ex ante, per se rule & $\begin{array}{l}\text { - Inferior to an ex post I approach if the entrant is as efficient as the incumbent or } \\
\text { only has a moderate efficiency advantage } \\
\text { - Superior to an ex post I approach if the entrant is very efficient and the incumbent } \\
\text { correspondingly makes huge losses while driving the entrant out of the market. An } \\
\text { ex ante approach would avoid these huge losses }\end{array}$ \\
\hline
\end{tabular}

Given the framework developed and analysis provided in this paper, a number of possible extension promise to add value. In addition to possible changes in the model or market specifications, especially the introduction of uncertainty and limited information can be expected to significantly alter the results. One key issue in this respect would be the 
consideration of the possibility of antitrust errors by the antitrust authority. Another issue which could be incorporated easily into the general framework are enforcement costs (which can be expected to differ significantly between the different enforcement options). Other possible extensions include the discounting of future profits or the consideration of further evaluation factors such as inter-industry robustness or the risk of regulatory capture.

In terms of important policy conclusions, the relevance of the above analysis can be separated into two channels: the refinement of the current predation enforcement regime and its amendment. While the former channel focuses on an increased role of interventions (especially fines) within the existing predation enforcement regime (which is applicable for all industries in an economy), the latter proposes the implementation of an additional enforcement approach for specific industries in which predation can be expected to be more likely and more harmful than in other industries.

With respect to the refinement of the current enforcement regime, the basic conclusion from the above analysis is that the current fine levels might be too weak to deter predation. However, a proposal to simply increase the fines for detected and convicted predators alone might be too weak to significantly amplify the deterrence effect, basically due to the very low probability of conviction. As a consequence, it might be worthwhile to consider the amendment of the current predation enforcement regime by the introduction of a prescreening approach which aims at identifying industries in which entry is difficult but desirable and a predation strategy might be a suitable instrument for an incumbent to fight such occasional entry attempts. In those industries, it makes sense to replace the ex post rule of reason approach with an ex ante per se rule approach as the latter keeps the entrant in the market and therefore preserves competition. Such an approach is likely to maximise the deterrent effect of predation enforcement without jeopardising the incentives of incumbents to implement procompetitive price reductions.

\section{Annex}

\subsection{Proof of Inequality (1)}

As discussed above, an initial welfare assessment has to compare the welfare situation of a successful predation strategy against the welfare realised if the monopoly situation in the prepredation period would have continued. Based on the setup shown in Figure 1, the welfare if predation is successful,

$$
\begin{gathered}
\mathrm{W}_{\text {Predation successful }}=\left[\left(\mathrm{t}^{\text {exit }}-\mathrm{t}^{\text {entry }}\right)\left(\mathrm{CS}^{\text {Pred }}\right)\right]+\left[\left(\mathrm{t}^{\text {end }}-\mathrm{t}^{\text {exit }}\right)\left(\mathrm{CS}^{\text {Mono }}\right)\right]+ \\
\left\lfloor\left(\mathrm{t}^{\text {exit }}-\mathrm{t}^{\text {entry }}\right)\left(\pi_{\mathrm{E}}^{\text {Pred }}\right)\right]+\left[\left(\mathrm{t}^{\text {exit }}-\mathrm{t}^{\text {entry }}\right)\left(\pi_{\mathrm{I}}^{\text {Pred }}\right)+\left(\mathrm{t}^{\text {end }}-\mathrm{t}^{\text {exit }}\right)\left(\pi_{\mathrm{I}}^{\text {Mono }}\right)\right],
\end{gathered}
$$

has to be larger than the welfare realised in the case of continuous monopoly,

$$
\begin{gathered}
\mathrm{W}_{\text {Continuous Monopoly }}=\left[\left(\mathrm{t}^{\text {exit }}-\mathrm{t}^{\text {entry }}\right)\left(\mathrm{CS}^{\text {Mono }}\right)\right]+\left[\left(\mathrm{t}^{\text {end }}-\mathrm{t}^{\text {exit }}\right)\left(\mathrm{CS}^{\text {Mono }}\right)\right]+ \\
{\left[\left(\mathrm{t}^{\text {exit }}-\mathrm{t}^{\text {entry }}\right)\left(\pi_{\mathrm{I}}^{\text {Mono }}\right)\right]+\left[\left(\mathrm{t}^{\text {end }}-\mathrm{t}^{\text {exit }}\right)\left(\pi_{\mathrm{I}}^{\text {Mono }}\right)\right] .}
\end{gathered}
$$

Substituting $\left(t^{\text {exit }}-t^{\text {enrty }}\right)=\alpha$ and $\left(t^{\text {end }}-t^{\text {exit }}\right)=\beta$ and simplifying both expressions leads to

$$
\begin{gathered}
\mathrm{W}_{\text {Continuous Monopoly }}=\alpha\left(\mathrm{CS}^{\text {Mono }}+\pi_{\mathrm{I}}^{\text {Mono }}\right) \\
\mathrm{W}_{\text {Predation successful }}=\alpha\left(\mathrm{CS}^{\text {Pred }}+\pi_{\mathrm{E}}^{\text {Pred }}+\pi_{\mathrm{I}}^{\text {Pred }}\right) .
\end{gathered}
$$

Further simplifying and rearranging leads to

$$
\mathrm{CS}^{\text {Pred }}-\mathrm{CS}^{\text {Mono }}>\pi_{\mathrm{I}}^{\text {Mono }}-\left(\pi_{\mathrm{E}}^{\text {Pred }}+\pi_{\mathrm{I}}^{\text {Pred }}\right) \text {. }
$$




\subsection{Proof of Inequality (2)}

As discussed above, antitrust rules and interventions increase welfare as long as the overall welfare realised with such interventions,

$$
\begin{gathered}
\mathrm{W}_{\text {Antitrust }}=\left[\left(\mathrm{t}^{\text {exit }}-\mathrm{t}^{\text {entry }}\right)\left(\mathrm{CS}^{\text {Pred }}\right)+\left(\mathrm{t}^{\text {end }}-\mathrm{t}^{\text {exit }}\right)\left(\mathrm{CS}^{\text {Duo }}\right)\right]+ \\
{\left[\left(\mathrm{t}^{\text {exit }}-\mathrm{t}^{\text {entry }}\right)\left(\pi_{\mathrm{E}}^{\text {Pred }}\right)+\left(\mathrm{t}^{\text {end }}-\mathrm{t}^{\text {exit }}\right)\left(\pi_{\mathrm{E}}^{\text {Duo }}\right)\right]+} \\
{\left[\left(\mathrm{t}^{\text {exit }}-\mathrm{t}^{\text {entry }}\right)\left(\pi_{\mathrm{I}}^{\text {Pred }}\right)+\left(\mathrm{t}^{\text {end }}-\mathrm{t}^{\text {exit }}\right)\left(\pi_{\mathrm{I}}^{\text {Duo }}\right)\right],}
\end{gathered}
$$

is larger than the welfare realised when the incumbent can successfully apply a predation strategy

$$
\begin{gathered}
\mathrm{W}_{\text {No Antitrust }}=\left[\left(\mathrm{t}^{\text {exit }}-\mathrm{t}^{\text {entry }}\right)\left(\mathrm{CS}^{\text {Pred }}\right)\right]+\left[\left(\mathrm{t}^{\text {end }}-\mathrm{t}^{\text {exit }}\right)\left(\mathrm{CS}^{\text {Mono }}\right)\right]+ \\
{\left[\left(\mathrm{t}^{\text {exit }}-\mathrm{t}^{\text {entry }}\right)\left(\pi_{\mathrm{E}}^{\text {Pred }}\right)\right]+\left[\left(\mathrm{t}^{\text {exit }}-\mathrm{t}^{\text {entry }}\right)\left(\pi_{\mathrm{I}}^{\text {Pred }}\right)+\left(\mathrm{t}^{\text {end }}-\mathrm{t}^{\text {exit }}\right)\left(\pi_{\mathrm{I}}^{\text {Mono }}\right)\right] .}
\end{gathered}
$$

Substituting $\left(t^{\text {exit }}-t^{\text {enrty }}\right)=\alpha$ and $\left(t^{\text {end }}-t^{\text {exit }}\right)=\beta$ and simplifying both expressions leads to

$$
\begin{gathered}
\mathrm{W}_{\text {No Antitrust }}=\beta\left(\mathrm{CS}^{\text {Mono }}+\pi_{\mathrm{I}}^{\text {Mono }}\right), \\
\mathrm{W}_{\text {Antitrust }}=\beta\left(\mathrm{CS}^{\text {Duo }}+\pi_{\mathrm{E}}^{\text {Duo }}+\pi_{\mathrm{I}}^{\text {Duo }}\right) .
\end{gathered}
$$

Further simplifying and rearranging leads to

$$
\mathrm{CS}^{\text {Duo }}-\mathrm{CS}^{\mathrm{Mono}}>\pi_{\mathrm{I}}^{\mathrm{Mono}}-\left(\pi_{\mathrm{E}}^{\text {Duo }}+\pi_{\mathrm{I}}^{\text {Duo }}\right) .
$$

\subsection{Proof of Equalities (3) and (4)}

As discussed above, optimal fines can be calculated on a gain-basis and on a harm-basis. In the following, proofs for both fines are provided.

\section{Optimal gain-based fine}

The optimal gain-based fine for an antitrust violation is equal to the additional gain the offender realises due to its misbehaviour. In the setup of Figure 1, the optimal fine is therefore defined as the difference between the incumbent's overall profits realised under successful predation

$$
\pi_{\mathrm{I}}^{\text {Pred }}=\left[\left(\mathrm{t}^{\text {exit }}-\mathrm{t}^{\text {entry }}\right)\left(\pi_{\mathrm{I}}^{\text {Pred }}\right)\right]+\left[\left(\mathrm{t}^{\text {end }}-\mathrm{t}^{\text {exit }}\right)\left(\pi_{\mathrm{I}}^{\text {Mono }}\right)\right]
$$

and the incumbent's profit if it accommodates the entrant

$$
\pi_{\mathrm{I}}^{\text {Duo }}=\left\lfloor\left(\mathrm{t}^{\text {exit }}-\mathrm{t}^{\text {entry }}\right)\left(\pi_{\mathrm{I}}^{\text {Duo }}\right)\right]+\left[\left(\mathrm{t}^{\text {emd }}-\mathrm{t}^{\text {exit }}\right)\left(\pi_{\mathrm{I}}^{\text {Duo }}\right)\right] .
$$

Substituting $\left(t^{\text {exit }}-t^{\text {enrty }}\right)=\alpha$ and $\left(t^{\text {end }}-t^{\text {exit }}\right)=\beta$ and simplifying both expressions leads to

$$
\begin{gathered}
\pi_{\mathrm{I}}^{\text {Pred }}=\beta \pi_{\mathrm{I}}^{\text {Mono }}+\alpha \pi_{\mathrm{I}}^{\text {Pred }}, \\
\pi_{\mathrm{I}}^{\text {Duo }}=\beta \pi_{\mathrm{I}}^{\text {Duo }}+\alpha \pi_{\mathrm{I}}^{\text {Duo }} .
\end{gathered}
$$

Generally, the optimal gain-based fine is $\mathrm{F}_{\text {Gain based }}=\pi_{\mathrm{I}}^{\text {Pred }}-\pi_{\mathrm{I}}^{\text {Duo }}$. Using the expressions above leads to the following optimal gain-based fine:

$$
\mathrm{F}_{\text {Gain based }}=\beta\left(\pi_{\mathrm{I}}^{\text {Mono }}-\pi_{\mathrm{I}}^{\text {Duo }}\right)+\alpha\left(\pi_{\mathrm{I}}^{\text {Pred }}-\pi_{\mathrm{I}}^{\text {Duo }}\right) .
$$




\section{Optimal harm-based fine}

As explained in the text, the optimal harm-based fine refers to the 'net harm to others' caused by the violation. In the predation period, harm is therefore given by the sum of the difference between the duopoly and the predation consumer surpluses and the difference between the entrant's duopoly and predation profits

$$
\operatorname{Harm}_{\alpha}=\alpha\left(\left(\mathrm{CS}^{\text {Duo }}-\mathrm{CS}^{\text {Pred }}\right)+\left(\pi_{\mathrm{E}}^{\text {Duo }}-\pi_{\mathrm{E}}^{\text {Pred }}\right)\right] .
$$

If predation is successful, the net harm to others is given by the difference between the duopoly and the monopoly consumer surpluses and the entrant's duopoly profits (it would have earned without a successful predation strategy)

$$
\operatorname{Harm}_{\beta}=\beta\left[\left(\mathrm{CS}^{\text {Duo }}-\mathrm{CS}^{\text {Mono }}\right)+\pi_{\mathrm{E}}^{\text {Duo }}\right] .
$$

The optimal harm-based fine is therefore given by

$$
\mathrm{F}_{\text {Harm based }}=\alpha\left[\left(\mathrm{CS}^{\text {Duo }}-\mathrm{CS}^{\text {Pred }}\right)+\left(\pi_{\mathrm{E}}^{\text {Duo }}-\pi_{\mathrm{E}}^{\text {Pred }}\right)\right]+\beta\left[\left(\mathrm{CS}^{\text {Duo }}-\mathrm{CS}^{\text {Mono }}\right)+\pi_{\mathrm{E}}^{\text {Duo }}\right]
$$

An alternative definition of harm could be the cost that the violation has imposed on society. Such harm would ignore the distributive effects of a predation strategy (namely, the lower consumer surplus due to higher monopoly profits) and would only focus on the net welfare losses, which can be defined as the difference between the welfare level which would have been realised if the incumbent has accommodated the entrant

$$
\begin{aligned}
& \left.\mathrm{W}_{\text {Accommodated }}=\left[\left(\mathrm{t}^{\text {exit }}-\mathrm{t}^{\text {entry }}\right)\left(\mathrm{CS}^{\mathrm{Duo}}\right)\right]+\left(\mathrm{t}^{\text {end }}-\mathrm{t}^{\text {exit }}\right)\left(\mathrm{CS}^{\mathrm{Duo}}\right)++\left(\mathrm{e}^{\text {exit }}-\mathrm{t}^{\text {entry }}\right)\left(\pi_{\mathrm{E}}^{\text {Duo }}\right)\right]+ \\
& \left(\left(t^{\text {end }}-t^{\text {exit }}\right)\left(\pi_{\mathrm{E}}^{\text {Duo }}\right)\right]+\left[\left(t^{\text {exit }}-t^{\text {entry }}\right)\left(\pi_{\mathrm{I}}^{\text {Duo }}\right)\right]+\left[\left(t^{\text {end }}-t^{\text {exit }}\right)\left(\pi_{\mathrm{I}}^{\text {Duo }}\right)\right] \text {, }
\end{aligned}
$$

and the welfare level which would have been realised if the incumbent has successfully applied a predation strategy

$$
\left[\left(t^{\text {exit }}-t^{\text {entry }}\right)\left(\pi_{\mathrm{E}}^{\text {Pred }}\right)\right]+\left[\left(t^{\text {exit }}-t^{\text {entry }}\right)\left(\pi_{\mathrm{I}}^{\text {Pred }}\right)+\left(t^{\text {end }}-t^{\text {exit }}\right)\left(\pi_{\mathrm{I}}^{\text {Mono }}\right)\right] .
$$

Substituting $\left(t^{\text {exit }}-t^{\text {enrty }}\right)=\alpha$ and $\left(t^{\text {end }}-t^{\text {exit }}\right)=\beta$ and simplifying both expressions leads to

$$
\begin{gathered}
\mathrm{W}_{\text {Accommodated }}=(\alpha+\beta)\left(\mathrm{CS}^{\text {Duo }}+\pi_{\mathrm{E}}^{\text {Duo }}+\pi_{\mathrm{I}}^{\text {Duo }}\right), \\
\mathrm{W}_{\text {Predation successful }}=\alpha\left(\mathrm{CS}^{\text {Pred }}+\pi_{\mathrm{E}}^{\text {Pred }}+\pi_{\mathrm{I}}^{\text {Pred }}\right)+\beta\left(\mathrm{CS}^{\text {Mono }}+\pi_{\mathrm{I}}^{\text {Mono }}\right) .
\end{gathered}
$$

The optimal harm-based fine would then be given by

$$
\begin{gathered}
\mathrm{F}_{\text {Harm based }}=(\alpha+\beta)\left(\mathrm{CS}^{\text {Duo }}+\pi_{\mathrm{E}}^{\text {Duo }}+\pi_{\mathrm{I}}^{\text {Duo }}\right)- \\
\left\{\alpha\left(\mathrm{CS}^{\text {Pred }}+\pi_{\mathrm{E}}^{\text {Pred }}+\pi_{\mathrm{I}}^{\text {Pred }}\right)+\beta\left(\mathrm{CS}^{\text {Mono }}+\pi_{\mathrm{I}}^{\text {Mono }}\right)\right\} .
\end{gathered}
$$

It can be shown (e.g., with the model and market specification used above) that such an alternative definition of harm typically cannot reach a deterrence effect, as the gains of the violation are typically greater than the 'optimal' harm-based fine. Only if the entrant has a large efficiency advantage would this definition of a harm-based fine lead to a deterrence effect.

\subsection{Proof of Inequality (6)}

The choice between an ex post I approach and an ex post II approach with an optimal fine can be expressed as follows. In an ex post I approach the overall welfare is given by 


$$
\begin{gathered}
\mathrm{W}_{\text {Ex post }}=\left\lfloor\left(\mathrm{t}^{\text {exit }}-\mathrm{t}^{\text {entry }}\right)\left(\mathrm{CS}^{\text {Pred }}\right)+\left(\mathrm{t}^{\text {end }}-\mathrm{t}^{\text {exit }}\right)\left(\mathrm{CS}^{\text {Duo }}\right)\right]+ \\
{\left[\left(\mathrm{t}^{\text {exit }}-\mathrm{t}^{\text {entry }}\right)\left(\pi_{\mathrm{E}}^{\text {Pred }}\right)+\left(\mathrm{t}^{\text {end }}-\mathrm{t}^{\text {exit }}\right)\left(\pi_{\mathrm{E}}^{\text {Duo }}\right)\right]+} \\
{\left[\left(\mathrm{t}^{\text {exit }}-\mathrm{t}^{\text {entry }}\right)\left(\pi_{\mathrm{I}}^{\text {Pred }}\right)+\left(\mathrm{t}^{\text {end }}-\mathrm{t}^{\text {exit }}\right)\left(\pi_{\mathrm{I}}^{\text {Duo }}\right)\right\rfloor .}
\end{gathered}
$$

As shown above, the optimal fine is 0 in an ex post I approach, as the predator did not cause any harm. The overall welfare in an ex post II approach with an optimal fine is given by

$$
\begin{gathered}
\mathrm{W}_{\text {Ex post II }}=\left[\left(\mathrm{t}^{\text {exit }}-\mathrm{t}^{\text {entry }}\right)\left(\mathrm{CS}^{\text {Pred }}\right)\right]+\left[\left(\mathrm{t}^{\text {end }}-\mathrm{t}^{\text {exit }}\right)\left(\mathrm{CS}^{\text {Mono }}\right)\right]+ \\
{\left[\left(\mathrm{t}^{\text {exit }}-\mathrm{t}^{\text {entry }}\right)\left(\pi_{\mathrm{E}}^{\text {Pred }}\right)\right]+\left\lfloor\left(\mathrm{t}^{\text {exit }}-\mathrm{t}^{\text {entry }}\right)\left(\pi_{\mathrm{I}}^{\text {Pred }}\right)+\left(\mathrm{t}^{\text {end }}-\mathrm{t}^{\text {exit }}\right)\left(\pi_{\mathrm{I}}^{\text {Mono }}\right)\right]+} \\
\left\{\alpha\left(\left[\mathrm{CS}^{\text {Duo }}-\mathrm{CS}^{\text {Pred }}\right)+\left(\pi_{\mathrm{E}}^{\text {Duo }}-\pi_{\mathrm{E}}^{\text {Pred }}\right)\right]\right\}+\varepsilon\left[\left(\mathrm{CS}^{\text {Duo }}-\mathrm{CS}^{\text {Mono }}\right)+\pi_{\mathrm{E}}^{\text {Duo }}\right] .
\end{gathered}
$$

The welfare realised is just the welfare in an approach where the antitrust authority does not intervene and the welfare of collecting the optimal fine after $\varepsilon$ periods. As the predator successfully reached the exit of the entrant, he can still charge monopoly prices for the remaining $\beta-\varepsilon$ periods.

Substituting $\left(t^{\text {exit }}-t^{\text {enrty }}\right)=\alpha$ and $\left(t^{\text {end }}-t^{\text {exit }}\right)=\beta$ and simplifying both expressions leads to

$$
\begin{gathered}
\mathrm{W}_{\text {Ex postI }}=\beta\left(\mathrm{CS}^{\text {Duo }}+\pi_{\mathrm{E}}^{\text {Duo }}+\pi_{\mathrm{I}}^{\text {Duo }}\right), \\
\mathrm{W}_{\text {Ex post II }}=\beta\left(\mathrm{CS}^{\text {Mono }}+\pi_{\mathrm{I}}^{\text {Mono }}\right)+ \\
\left.\left\{\alpha\left[\left(\mathrm{CS}^{\text {Duo }}-\mathrm{CS}^{\text {Pred }}\right)+\left(\pi_{\mathrm{E}}^{\text {Duo }}-\pi_{\mathrm{E}}^{\text {Pred }}\right)\right]\right\}+\varepsilon\left[\left(\mathrm{CS}^{\text {Duo }}-\mathrm{CS}^{\text {Mono }}\right)+\pi_{\mathrm{E}}^{\text {Duo }}\right]\right\} .
\end{gathered}
$$

The welfare differential can be calculated by subtracting $\mathrm{W}_{\text {Ex post II }}$ from $\mathrm{W}_{\text {Ex post } \mathrm{I}}$. The value of the positive differential shows how much the antitrust authority should invest at the maximum in the quicker but more expensive ex post I approach to increase overall welfare compared to an ex post II approach.

\subsection{Proof of Inequality (8)}

As discussed above, an alternative to ex post antitrust rules is ex ante antitrust rules. If such rules work frictionless they turn predation into an unprofitable strategy before it is actually played by the incumbent. Consequently, the entrant will be accommodated under such a regime.

Ex ante rules are superior to ex post rules if the welfare realised under the former regime,

$$
\begin{gathered}
\mathrm{W}_{\text {Ex }- \text { ante rule }}=\left[\left(\mathrm{t}^{\text {exit }}-\mathrm{t}^{\text {entry }}\right)\left(\mathrm{CS}^{\text {Duo }}\right)+\left(\mathrm{t}^{\text {end }}-\mathrm{t}^{\text {exit }}\right)\left(\mathrm{CS}^{\text {Duo }}\right)\right]+ \\
{\left[\left(\mathrm{t}^{\text {exit }}-\mathrm{t}^{\text {entry }}\right)\left(\pi_{\mathrm{E}}^{\text {Duo }}\right)+\left(\mathrm{t}^{\text {end }}-\mathrm{t}^{\text {exit }}\right)\left(\pi_{\mathrm{E}}^{\text {Duo }}\right)\right]+} \\
{\left[\left(\mathrm{t}^{\text {exit }}-\mathrm{t}^{\text {entry }}\right)\left(\pi_{\mathrm{I}}^{\text {Duo }}\right)+\left(\mathrm{t}^{\text {end }}-\mathrm{t}^{\text {exit }}\right)\left(\pi_{\mathrm{I}}^{\text {Duo }}\right)\right] .}
\end{gathered}
$$

is larger than the welfare realised under an ex post regime,

$$
\begin{gathered}
\mathrm{W}_{\text {Ex }- \text { post rule }}=\left[\left(\mathrm{t}^{\text {exit }}-\mathrm{t}^{\text {entry }}\right)\left(\mathrm{CS}^{\text {Pred }}\right)+\left(\mathrm{t}^{\text {end }}-\mathrm{t}^{\text {exit }}\right)\left(\mathrm{CS}^{\text {Duo }}\right)\right]+ \\
{\left[\left(\mathrm{t}^{\text {exit }}-\mathrm{t}^{\text {entry }}\right)\left(\pi_{\mathrm{E}}^{\text {Pred }}\right)+\left(\mathrm{t}^{\text {end }}-\mathrm{t}^{\text {exit }}\right)\left(\pi_{\mathrm{E}}^{\text {Duo }}\right)\right]+} \\
{\left[\left(\mathrm{t}^{\text {exit }}-\mathrm{t}^{\text {entry }}\right)\left(\pi_{\mathrm{I}}^{\text {Pred }}\right)+\left(\mathrm{t}^{\text {end }}-\mathrm{t}^{\text {exit }}\right)\left(\pi_{\mathrm{I}}^{\text {Duo }}\right)\right] .}
\end{gathered}
$$

Substituting $\left(\mathrm{t}^{\text {exit }}-\mathrm{t}^{\text {enrty }}\right)=\alpha$ and $\left(\mathrm{t}^{\text {end }}-\mathrm{t}^{\text {exit }}\right)=\beta$ and simplifying both expressions leads to

$$
\begin{gathered}
\mathrm{W}_{\mathrm{Ex}-\text { anterule }}=\alpha\left(\mathrm{CS}^{\text {Duo }}+\pi_{\mathrm{E}}^{\text {Duo }}+\pi_{\mathrm{I}}^{\text {Duo }}\right), \\
\mathrm{W}_{\mathrm{Ex}-\text { post rule }}=\alpha\left(\mathrm{CS}^{\text {Pred }}+\pi_{\mathrm{E}}^{\text {Pred }}+\pi_{\mathrm{I}}^{\text {Pred }}\right) .
\end{gathered}
$$


Further simplifying and rearranging leads to

$$
\mathrm{CS}^{\text {Duo }}-\mathrm{CS}^{\text {Pred }}>\pi_{\mathrm{E}}^{\text {Pred }}+\pi_{\mathrm{I}}^{\text {Pred }}-\pi_{\mathrm{E}}^{\text {Duo }}-\pi_{\mathrm{I}}^{\text {Duo }} .
$$

\section{References}

Areeda, P. and D. Turner (1975), Predatory Pricing and Related Practices under Section 2 of the Sherman Act, Harvard Law Review 88, 697-733.

Baumol, W. (1996), Predation and the Logic of the Average Variable Cost Test, Journal of Law and Economics, Vol. 39, 49-72.

Baumol, W. (1979), Quasi-Permanence of Price Reductions: A Policy for Prevention of Predatory Pricing, Yale Law Journal, Vol. 89, 1-26.

Becker, G. (1968), Crime and Punishment: An Economic Approach, Journal of Political Economy 76, 169-217.

Bolton, P., J. Brodley and M. Riordan (2000), Predatory Pricing: Strategic Theory and Legal Policy, Georgetown Law Review 88, 2239-2330.

Brodley, J. and G. Hay (1981), Predatory Pricing. Competing Economic Theories and the Evolution of Legal Standards, Cornell Law Review 66, 738-803.

Cabral, L. and M. Riordan (1997), The Learning Curve, Predation, Antitrust, and Welfare, Journal of Industrial Economics 45, 55-169.

Connor, J. and R. Lande (2006), The Size of Cartel Overcharges, Antitrust Bulletin 51, 9831022.

Edwards, G. (2002), The Perennial Problem of Predatory Pricing, Australian Business Law Review 30, 170-201.

Farrell, J. and M. Katz (2001), Competition or Predation? Schumpeterian Rivalry in Network Markets, Working Paper, University of California at Berkeley.

Frontier Economics (2002), How Low Can You Go? - Minimising the Pain of Price Wars, Strategy Bulletin, London.

Hüschelrath, K. and J. Weigand (2010), A Framework to Enforce Anti-Predation Rules, forthcoming World Competition Law and Economics Review.

Joskow, P. and A. Klevorick (1979), A Framework for Analyzing Predatory Pricing Policy, Yale Law Journal 89, 213-270.

Kate, A. and G. Niels (2004), Below Cost Pricing in the Presence of Network Externalities, in: Swedish Competition Authority (Ed.), The Pros and Cons of Low Prices, Göteborg, 97-127.

Kate, A. and G. Niels (2002), On the Rationality of Predation: The Debate between Chicago and Post-Chicago, Antitrust Bulletin 47, 1-24.

Lande, R. (2004), Why Antitrust Damage Levels Should be Raised, Loyola Consumer Law Review 16, 329-345.

Landes, W. (1983), Optimal Sanctions for Antitrust Violations, University of Chicago Law Review 50, 652-678.

Martin, S. (1994), Industrial Economics, Englewood Cliffs.

Mastromanolis, E. (1998), Predatory Pricing Strategies in the European Union: A Case for Legal Reform, European Competition Law Review 19, 211-224.

Normann, H.-T. (1994), Stackelberg Warfare as an Equilibrium Choice in a Game with Reputation Effects, EUI Working Paper ECO No. 94/43, Florence.

OECD (2007), Remedies and Sanctions in Abuse of Dominance Cases, Paris.

Oster, C. and J. Strong (2001), Predatory Practices in the U.S. Airline Industry, Working Paper, Indiana University, Bloomington.

Phlips, L. (1995), Competition Policy: A Game-Theoretic Perspective, Cambridge.

Williamson, O. (1977), Predation: A Strategic and Welfare Analysis, Yale Law Journal 87, 284-340.

Wils, W. (2002), The Optimal Enforcement of EC Antitrust Law, The Hague. 